\title{
Multiscale soil moisture estimates using static and roving cosmic-ray soil moisture sensors
}

\author{
David McJannet ${ }^{1}$, Aaron Hawdon ${ }^{2}$, Brett Baker ${ }^{2}$, Luigi Renzullo ${ }^{3}$, and Ross Searle ${ }^{1}$ \\ ${ }^{1}$ CSIRO Land and Water, EcoSciences Precinct, Dutton Park, Brisbane, QLD, Australia \\ ${ }^{2}$ CSIRO Land and Water, ATSIP, James Cook University, Townsville, QLD, Australia \\ ${ }^{3}$ CSIRO Land and Water, Canberra, ACT, Australia \\ Correspondence to: David McJannet (david.mcjannet@csiro.au)
}

Received: 23 June 2017 - Discussion started: 12 July 2017

Revised: 22 September 2017 - Accepted: 29 October 2017 - Published: 1 December 2017

\begin{abstract}
Soil moisture plays a critical role in land surface processes and as such there has been a recent increase in the number and resolution of satellite soil moisture observations and the development of land surface process models with ever increasing resolution. Despite these developments, validation and calibration of these products has been limited because of a lack of observations on corresponding scales. A recently developed mobile soil moisture monitoring platform, known as the "rover", offers opportunities to overcome this scale issue. This paper describes methods, results and testing of soil moisture estimates produced using rover surveys on a range of scales that are commensurate with model and satellite retrievals. Our investigation involved static cosmic-ray neutron sensors and rover surveys across both broad $(36 \times 36 \mathrm{~km}$ at $9 \mathrm{~km}$ resolution) and intensive $(10 \times 10 \mathrm{~km}$ at $1 \mathrm{~km}$ resolution) scales in a cropping district in the Mallee region of Victoria, Australia. We describe approaches for converting rover survey neutron counts to soil moisture and discuss the factors controlling soil moisture variability. We use independent gravimetric and modelled soil moisture estimates collected across both space and time to validate rover soil moisture products. Measurements revealed that temporal patterns in soil moisture were preserved through time and regression modelling approaches were utilised to produce time series of property-scale soil moisture which may also have applications in calibration and validation studies or local farm management. Intensivescale rover surveys produced reliable soil moisture estimates at $1 \mathrm{~km}$ resolution while broad-scale surveys produced soil moisture estimates at $9 \mathrm{~km}$ resolution. We conclude that the multiscale soil moisture products produced in this study are
\end{abstract}

well suited to future analysis of satellite soil moisture retrievals and finer-scale soil moisture models.

\section{Introduction}

Soil moisture has a strong influence on land-atmosphere interactions, hydrological processes, ecosystem functioning and agricultural productivity. The importance of this variable has led to an increase in the number and resolution of satellite soil moisture observations and the ongoing development of finer-resolution land surface process models (Ochsner et al., 2013). Despite these developments, our ability to validate and/or calibrate these products is limited because of a lack of observations on matching scales. Satellite observations typically have resolutions in the order of 3 to $50 \mathrm{~km}$, while broad-area modelling of soil moisture variability typically occurs at resolutions $>1 \mathrm{~km}$. The scale of these products are orders of magnitude larger than those of traditional in situ sensors, which creates an issue because of the well-documented small-scale variability in soil moisture (Vereecken et al., 2014; Western and Blöschl, 1999). Some researchers have overcome this issue by establishing soil moisture monitoring networks (Bogena et al., 2010; Smith et al., 2012), but the extent of sensor networks is still relatively small $\left(<1 \mathrm{~km}^{2}\right)$.

More recently cosmic-ray neutron sensors (CRNSs) have been deployed to provide soil moisture estimates on the hectometre scale (circular footprint, 260-600 m diameter) (Desilets and Zreda, 2013; Köhli et al., 2015). CRNSs measure naturally generated neutrons that are produced by cosmic 
rays passing through the Earth's atmosphere. Recent measurement and modelling studies (Andreasen et al., 2017a, b) have shown that the CRNSs measure neutrons in both the thermal $(<1 \mathrm{eV})$ and epithermal ranges $(>1-1000 \mathrm{eV})$ and that sensitivities to energy range vary with environmental features present at a site (e.g. tree canopy, crop, litter). The neutron intensity above the soil surface is inversely correlated with soil moisture as it responds to the hydrogen contained in the soil and plant water and to a lesser degree to plant and soil carbon compounds (Desilets et al., 2010). The scale match between the CRNS technique and satellite observations has led to a number of recent studies which compare CRNS observations to satellite observations (Renzullo et al., 2014; Montzka et al., 2017; Kędzior and Zawadzki, 2016) and land surface models (Vinodkumar et al., 2017; Holgate et al., 2016) and use CRNS observation to parameterise models (Baatz et al., 2017; Rivera Villarreyes et al., 2014). Development of networks of CRNS across a number of countries (e.g. USA: Zreda et al., 2012; UK: Evans et al., 2016, Germany; Baatz et al., 2014; and Australia: Hawdon et al., 2014) is providing useful time series of soil moisture information which will be valuable for years to come.

While the CRNS provides a better match to the scale of satellite retrievals and model estimates there is still a scale mismatch that prevents direct full-scale validation of these products. To address this, a mobile CRNS, called the cosmicray rover, has been developed (Desilets et al., 2010). The rover uses the same technology as the CRNS but its design allows for mobile mapping of soil moisture across the landscape. This mobile mapping capability allows for soil moisture surveys to be undertaken over areas commensurate with satellite pixels or model domains, thereby filling the gap in soil moisture observations (Chrisman and Zreda, 2013). The earliest use of the cosmic-ray rover was for repeated surveys across an area of $25 \times 40 \mathrm{~km}$ in the Tucson Basin in order to produce a catchment-scale water balance (Chrisman and Zreda, 2013). Dong et al. (2014) used a rover to map soil moisture on multiple occasions over a $16 \times 10 \mathrm{~km}$ and a $34 \times 14 \mathrm{~km}$ region in Oklahoma with the aim of evaluating satellite soil moisture estimates. More recently Franz et al. (2015) combined rover surveys over a $12 \times 12 \mathrm{~km}$ area in Nebraska with CRNS measurements to develop a technique for multiscale real-time soil moisture monitoring.

This paper describes part of a research project aimed at producing soil moisture estimates on a range of scales for eventual comparison to satellite and modelled soil moisture estimates. The focus of this paper is on establishing techniques for producing spatial representations of soil moisture using CRNSs and a cosmic-ray rover. We will present a nested set of broad-scale and intensive-scale rover survey results which were collected across a $36 \times 36 \mathrm{~km}$ area in a cropping district in the Mallee region of Victoria, Australia, and we will describe techniques used to convert rover measurements into soil moisture estimates using CRNSs and spatial soil property information. Using statistical relationships between property-scale soil moisture from rover surveys and CRNSs, we will present a simple approach for producing real-time property-scale soil moisture estimates in the local area. We also use our observations on different scales to test the reliability of our experimental design.

\section{Methods}

\subsection{Site description}

The study area is located in the Shire of Buloke in the Mallee region of Victoria, Australia (Fig. 1). The measurement campaign took place across a $36 \times 36 \mathrm{~km}$ region centred on $-35.684^{\circ} \mathrm{S}, 142.858^{\circ} \mathrm{E}$, which lies between the towns of Birchip to the south and Sea Lake to the north. The Mallee is a rain-fed agricultural region with wheat and barley being widely grown. Much of the native vegetation has been removed since European settlement. In the region of interest the landscape is flat with an elevation ranging between 50 to $120 \mathrm{~m}$ a.s.l. The climate of the area is classified as semi-arid with an average annual rainfall of $368 \mathrm{~mm}$, an average daily minimum temperature in July of $3.6^{\circ} \mathrm{C}$ and an average daily maximum temperature in January of $30.7^{\circ} \mathrm{C}$ (Anwar et al., 2007).

\subsection{Static cosmic-ray neutron sensors}

Cosmic-ray neutron sensors were installed at two locations in the designated field survey area (Fig. 1). These two locations are named Bishes (northern probe) and Bennetts (southern probe). Each of these sensors included a single polyethylene shielded cosmic-ray probe (CRP-1000B, Hydroinnova, Albuquerque, USA), which monitors neutron intensity in the epithermal to fast neutron energy range. Each system also measured barometric pressure, temperature and relative humidity, which are required for measurement correction procedures. The system was programmed to record data at hourly intervals and was sent via satellite telemetry (Iridium SBD services) in near-real-time to a database on a remote server (http://cosmoz.csiro.au) (Hawdon et al., 2014). Prior to deployment, the two static sensors were run side-byside for a period of 4 days to determine if there were any differences in counting rates that were not attributable to local conditions. Over this period the average counting rate differed by less than $1 \%$, thus giving confidence that differences between sensors reflect local site characteristics alone.

In order to isolate the effect of soil moisture on neutron count measurements it is first necessary to remove variation due to other environmental factors. The largest correction that is required is an adjustment for changes in atmospheric pressure, but there are also corrections required for changes in atmospheric water vapour and changes in the intensity of the incoming neutron flux. The standard correction procedures implemented across the CosmOz network have been 


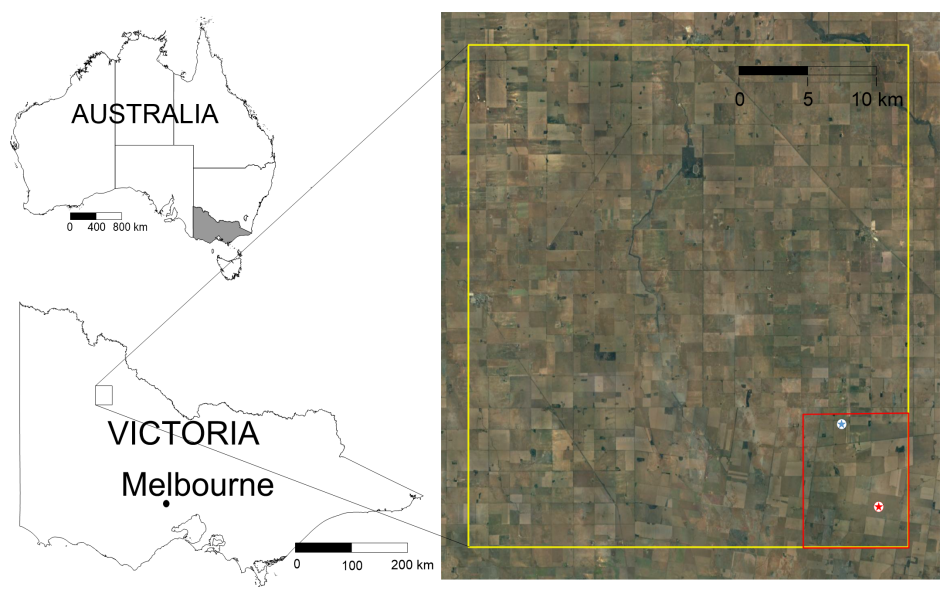

Figure 1. Location of field site in western Victoria, Australia. The yellow rectangle shows extent of broad-scale rover surveys $(36 \times 36 \mathrm{~km})$ and the red rectangle shows extent of intensive surveys $(10 \times 10 \mathrm{~km})$. Blue and red stars indicate the location of the Bishes and Bennetts cosmic-ray neutron sensors. Imagery data: Google, TerraMetrics 2017.

described in detail by Hawdon et al. (2014), and therefore only a brief summary will be provided here.

Cosmic-ray neutron intensity is particularly sensitive to elevation or the mass of air above the sensor, which is accounted for by the by the correction factor, $f_{P}$, which is defined as an exponential relationship with barometric pressure (Zreda et al., 2008):

$f_{P}=\exp \left[\beta\left(P-P_{\text {ref }}\right)\right]$,

where $P$ is atmospheric pressure (mbar) and $P_{\text {ref }}$ is the reference atmospheric pressure (mbar), which is calculated using standard formulas based on site elevation (NASA, 1976). The atmospheric attenuation coefficient $\left(\beta, \mathrm{cm}^{2} \mathrm{~g}^{-1}\right.$ or $\left.\mathrm{mbar}^{-1}\right)$ for neutron-generating cosmic rays has been calculated for each of our sites using the method described by Desilets et al. (2006).

Water vapour in the atmosphere has the same neutronmoderating capacity as water in the soil and as such will influence the total neutron count (Zreda et al., 2012). A correction factor for atmospheric water vapour effects was developed by Rosolem et al. (2013) and it utilises near-surface absolute humidity $\left(\rho_{\mathrm{v} 0}, \mathrm{~g} \mathrm{~m}^{-3}\right)$, which is derived from measurements of temperature, atmospheric pressure and humidity. The correction factor for atmospheric water vapour $\left(f_{\mathrm{wv}}\right)$ is derived from the following:

$f_{\mathrm{wv}}=1+0.0054\left(\rho_{\mathrm{v} 0}-\rho_{\mathrm{v} 0}^{\mathrm{ref}}\right)$,

where $\rho_{\mathrm{v} 0}^{\text {ref }}$ is the reference absolute humidity, which we set to $0 \mathrm{~g} \mathrm{~m}^{-3}$ (i.e. dry air).

To account for variations in incoming neutron flux an intensity correction factor is calculated by normalising the source intensity to a fixed point in time (Zreda et al., 2012). The correction factor for incoming neutron intensity $\left(f_{\mathrm{i}}\right)$ is expressed as follows:

$f_{\mathrm{i}}=\frac{I_{\mathrm{m}}}{I_{\mathrm{ref}}}$,

where $I_{\mathrm{m}}$ is the selected neutron monitor counting rate at any particular point in time and $I_{\text {ref }}$ is a reference counting rate for the same neutron monitor from an arbitrary fixed point in time which is 1 May 2011. Neutron monitor data are sourced from the Neutron Monitor Database (NMDB; http://www.nmdb.eu). Both of these sites utilise data from the Lomnický štít Observatory in Slovakia.

The counting rate is also scaled to sea level and high latitude to enable comparison between sensors. Scaling factors for converting counting rate to sea level $\left(f_{\mathrm{s}}\right)$ and high latitude $\left(f_{1}\right)$ are described by Desilets and Zreda (2003) and Desilets et al. (2006).

Final corrected counts $(N)$ are calculated using the following equation:

$N=N_{\text {raw }}\left(\frac{f_{P} f_{\mathrm{wv}}}{f_{\mathrm{i}}}\right)\left(\frac{f_{\mathrm{s}}}{f_{\mathrm{l}}}\right)$,

where $N_{\text {raw }}$ is the uncorrected neutron count from the CRP. Corrected neutron counts were converted to volumetric soil moisture content $(\theta)$ using the calibration function generated by Desilets et al. (2010) and modified by Bogena et al. (2013):

$\theta=\left(\frac{0.0808}{\left(\frac{N}{N_{0}}\right)-0.372}-0.115-w_{\text {lat }}-w_{\text {SOM }}\right) \rho_{\mathrm{bd}}$,

where $N_{0}$ is the neutron intensity in air above a dry soil which is obtained from field calibration, $w_{\text {lat }}$ is lattice water content of the soil, $w_{\text {SOM }}$ is soil organic matter expressed as a water equivalent (see below), and $\rho_{\mathrm{bd}}$ is bulk density of the soil. 
Field calibration at each site involved collection of gravimetric and volumetric soil samples at three distances from the probe $(25,100$ and $200 \mathrm{~m})$ along each cardinal and intercardinal direction (i.e. 8 radial directions). At each sample point, soil cores were taken to calculate volumetric soil moisture content for three depths ( 0 to 5,10 to 15 and 25 to $30 \mathrm{~cm}$ ), giving a total of 72 samples per calibration. Water content from samples was determined by drying samples at $105^{\circ} \mathrm{C}$ for $24 \mathrm{~h}$ (Klute, 1986). The depth-weighted soil moisture from field calibration was calculated using the method proposed by Franz et al. (2012) and corresponding corrected neutron count is used to determine $N_{0}$ in Eq. (5). Hydrogen held within the lattice structure of the soil minerals and organic material can also effect neutron count rate and, hence, need to be considered in calculation procedures. Lattice water $\left(w_{\text {lat }}\right)$ was determined from the amount of water released at $1000^{\circ} \mathrm{C}$ preceded by drying at $105^{\circ} \mathrm{C}$. Soil organic carbon was estimated by measuring total organic carbon in samples using Heanes wet oxidation, method 6B1 in Rayment and Higginson (1992). Following Franz et al. (2013) and Bogena et al. (2013), the organic carbon was assumed to be present as cellulose, $\mathrm{C}_{6} \mathrm{H}_{10} \mathrm{O}_{5}$, and this was converted into an equivalent amount of water $\left(w_{\mathrm{SOM}}\right)$ by multiplying measured soil organic carbon by 0.556 , which is the ratio of 5 times the molecular weight of water to the molecular weight of cellulose.

\subsection{Rover system}

The rover system is based around a set of 16 custommade tube capsules supplied by Hydroinnova (Albuquerque, USA), which are similar to those used for the static cosmicray neutron sensors but larger. The rover has counting rates approximately 18 times greater than that of a standard static sensor under the same condition, thus allowing for measurements to be made at $1 \mathrm{~min}$ intervals. For a volumetric soil moisture content of $10 \%$ a count rate of around 350 counts per minute was recorded. The set of 16 tubes is mounted in a trailer from which additional measurements of air temperature, relative humidity, atmospheric pressure and location were also made. Pictures of the rover system are available on the CosmOz web page (http://cosmoz.csiro.au/ about-cosmoz/). While mobile, the measurements from the system were monitored in real-time on a screen in the cabin of the tow vehicle. A dash mounted camera was also used to collect images at one minute intervals during the survey.

For this investigation a nested design of broad-scale and intensive localised measurements was implemented. The broad-scale design included a survey over an area with dimensions of approximately $36 \times 36 \mathrm{~km}$ which encapsulated a single Soil Moisture Active Passive (SMAP) satellite pixel. Using typical counting rates for this area and by targeting an output resolution for soil moisture of $9 \times 9 \mathrm{~km}$, we calculated that the maximum driving speed for this survey was $90 \mathrm{~km} \mathrm{~h}^{-1}$. This provided a good density of measurement points for interpolation purposes. The survey area and measurement points from the driving track are shown in Fig. 2. The broad-scale surveys typically took $10 \mathrm{~h}$ to complete, involved over 600 measurements and the average speed travelled was around $60 \mathrm{~km} \mathrm{~h}^{-1}$. The intensive-scale survey covered an area of approximately $10 \times 10 \mathrm{~km}$ and was located in the south-eastern corner of the broad-scale survey (Fig. 2). In this survey a target resolution for soil moisture of $1 \times 1 \mathrm{~km}$ was used for which we calculated that the maximum driving speed should not exceed $30 \mathrm{~km} \mathrm{~h}^{-1}$. Much of the driving for the intensive-scale surveys was around field boundaries and on unsealed roads. At $1 \mathrm{~km}$ resolution the intensive-scale survey results were well matched to farm property scale in this region. Intensive-scale surveys also took approximately $10 \mathrm{~h}$ to complete with more than 600 measurement point being collected. The average speed during these surveys was $20 \mathrm{~km} \mathrm{~h}^{-1}$. Survey tracks were defined for both surveys prior to undertaking measurement using maps of the local road network. These maps were loaded into GIS software and were used to guide navigation on each survey run.

The nested design of the intensive- and broad-scale surveys (Fig. 2) enables the accuracy of broad-scale survey estimates to be assessed. To undertake such an analysis we selected a $9 \times 9 \mathrm{~km}$ area within the area of survey overlap (Fig. 2) and derived corresponding soil moisture at resolutions of 1,3 and $9 \mathrm{~km}$. In such an analysis the intensive survey results are considered as a point of truth for broad survey results.

As well as enabling production of direct farm propertyscale estimates at the time of the surveys, the intensive-scale survey results were used to derive a soil moisture product of much higher time resolution on the property scale. This was achieved using spatial regression analysis with the continuous soil moisture measurements at the static CRNS observations at Bennetts. Linear regression equations were derived for each property by comparing the soil moisture content at the Bennetts CRNS versus the corresponding rover survey soil moisture for each property in turn. Using this approach, regression relationships were developed between the Bennetts CRNS and 50 properties identified within the intensive survey area for the three surveys undertaken. These relationships enable production of continuous farm property scale in this area. This approach assumes that rainfall is relatively uniform across the region and that crops are planted across all periods, both of which are typical in this study area.

Procedures used for correcting static cosmic-ray neutron sensor counts (Eqs. 1 to 4 ) were also applied to the rover data. Continually varying elevation, location, pressure, temperature and humidity were used for these calculations. Soil moisture was also calculated in the same way as for the static sensors (Eq. 5) but there was a requirement for spatial information regarding bulk density, soil organic matter and lattice water content. The Soil and Landscape Grid of Australia provides $\sim 90 \times \sim 90 \mathrm{~m}$ pixels of digital soil attributes, including bulk density (Viscarra Rossel et al., 2014a) and soil 


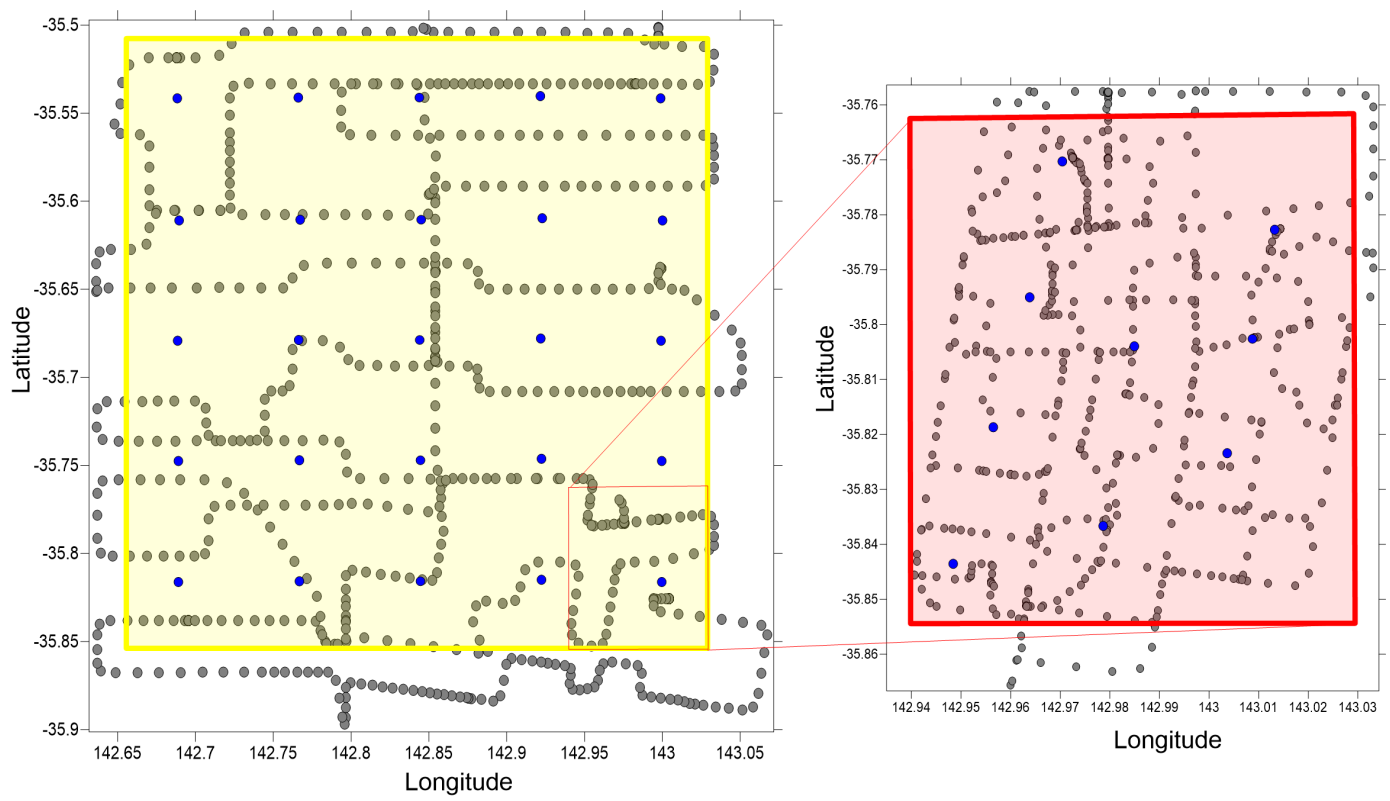

Figure 2. Rover survey extents and sampling points for the broad-scale and intensive-scale measurement campaigns. Sampling points from April 2016. The yellow box $(\sim 36 \mathrm{~km} \times 36 \mathrm{~km})$ delineates the broad-scale survey extent and the red box $(\sim 10 \mathrm{~km} \times 10 \mathrm{~km})$ delineates the intensive-scale survey extent. Blue points in each figure represent approximate locations of gravimetric soil moisture sampling points.

organic carbon (Viscarra Rossel et al., 2014b) at depths of 0$5,5-15$ and $15-30 \mathrm{~cm}$ which are useful for applying to rover surveys. The Soil and Landscape Grid of Australia does not provide any lattice water information but it does provide information on clay content (Viscarra Rossel et al., 2014c) and others (Greacen, 1981; Avery et al., 2016) have shown that clay content is often a good predictor of lattice water. In this study we investigated whether such a relationship exists for the soils in the study area. To do this we collected 36 samples for lattice water analysis; this included 25 distributed samples in the broad-scale survey area, 9 samples across the intensive-scale survey area and the 2 samples collected as part of the calibration of the static probes. These samples were from cores extracted from $0-30 \mathrm{~cm}$ depth. The spatial maps of bulk density, clay content and organic carbon used in the rover calculation procedures are shown in Fig. 3; also shown for site characterisation is the digital elevation model for the survey area.

Use of Eq. (5) in rover surveys also requires specification of a suitable $N_{0}$ value. For the static sensors this value is derived through the calibration procedures. To calculate $N_{0}$ for the rover we undertook side-by-side comparisons with the static sensors which involved parking next to a static sensor for $12 \mathrm{~h}$ prior to a survey. The average counts from the rover and static sensor were then compared to derive a suitable scaling approach to derive a rover-specific $N_{0}$. Similar cosmic-ray neutron sensor cross-calibrations were undertaken by Baatz et al. (2015) to account for sensor-specific differences. Both broad-scale and intensive-scale surveys were undertaken on three separate occasions on consecutive days during April 2016, June 2016 and March 2017.

Interpolation of the rover count data was required to produce a spatial representation of count rates for the entire survey area. To achieve this the Variogram Estimation and Spatial Prediction with Error (VESPER) software package (Minasny et al., 2005) was used. VESPER was used to undertake conventional kriging with a global variogram. An exponential variogram model was used for both survey scales and an interpolated grid of corrected rover count rate was produced at $90 \mathrm{~m}$ resolution to match that of the underlying soils information.

\subsection{Comparison datasets}

Two independent datasets were utilised for comparison to soil moisture estimates from our rover surveys: (1) opportunistic point samples collected during each survey and (2) modelled soil moisture estimates from the Australian Bureau of Meteorology's Australian Water Resources Assessment Landscape model, known as AWRA-L.

Soil samples were collected at approximate predefined points, as shown in Fig. 2, during each of the rover surveys. A full set of samples was collected during the April 2016 surveys and smaller sub-sets were collected during the later surveys. At each sampling location a single $0-30 \mathrm{~cm}$ core was extracted. Gravimetric water content for these cores was determined by drying samples at $105^{\circ} \mathrm{C}$ for $24 \mathrm{~h}$. For comparison purposes, rover volumetric soil moisture estimates for the nearest pixel $(9 \mathrm{~km}$ resolution for broad scale and $1 \mathrm{~km}$ 

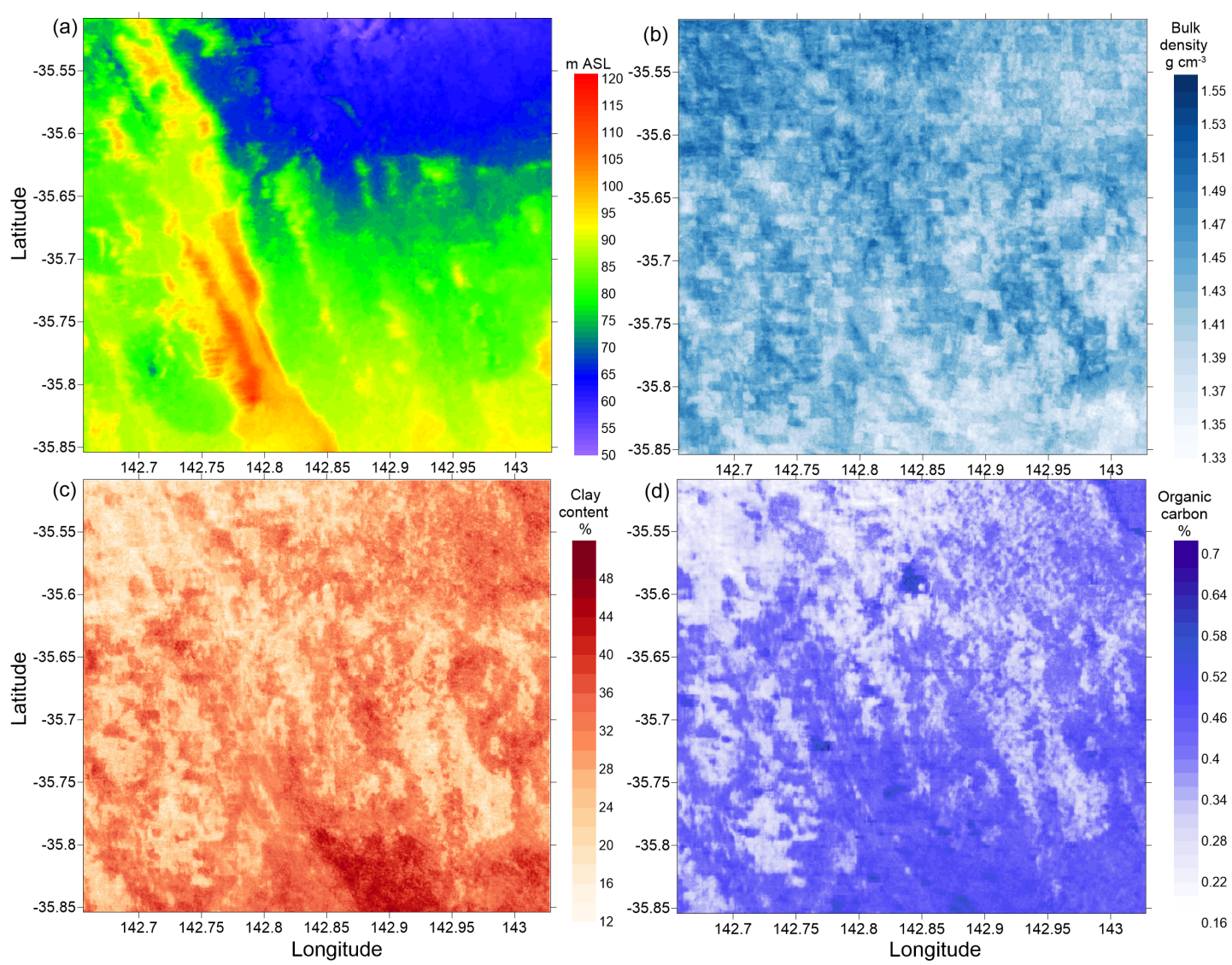

Figure 3. Field survey area DEM (a), depth-weighted 0-30 cm bulk density (b), depth-weighted 0-30 cm clay content (c) and depth-weighted 0-30 cm organic matter content $(\mathbf{d})$.

resolution for intensive) were extracted and divided by the corresponding average bulk density for that pixel to produce an equivalent gravimetric estimate of soil moisture. We note here that there is a large-scale discrepancy between these datasets and highlight that the point samples only offer an approximate guide as to the accuracy of rover survey results.

AWRA-L is a daily $0.05^{\circ}(\sim 5 \mathrm{~km})$ grid-based, distributed water balance model. It simulates the flow of water through the landscape with rainfall entering the grid cell through the vegetation and soil moisture stores and leaving the grid cell through evapotranspiration, runoff or deep drainage to the groundwater. The implementation and testing of the AWRA$\mathrm{L}$ model has been described by numerous authors (Wallace et al., 2013; Van Dijk, 2010; Viney et al., 2014). Of particular interest to this study is the AWRA-L estimate of root zone soil moisture which covers a depth of $0-100 \mathrm{~cm}$. The root zone represents a deeper soil zone than the effective depth of the rover but provides our best source of comparison data. When comparing $5 \mathrm{~km}$ resolution AWRA-L soil moisture estimates to those from the $9 \mathrm{~km}$ resolution broad-scale rover survey, the nearest AWRA-L pixel to the $9 \mathrm{~km}$ pixel centroid was used. When comparing the AWRA-L soil moisture to the $1 \mathrm{~km}$ resolution intensive-scale survey, the intensive-scale

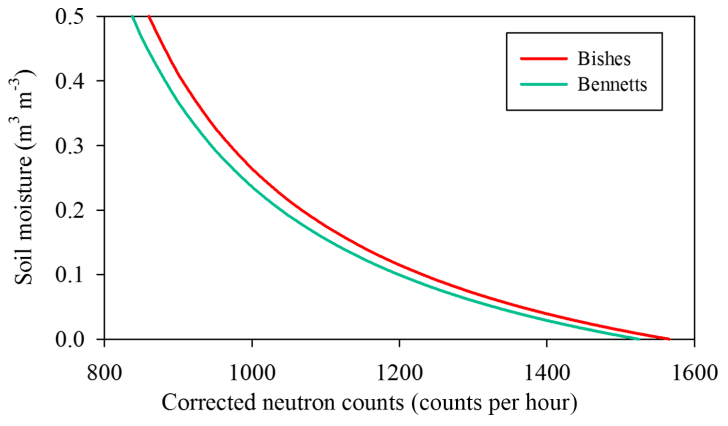

Figure 4. Calibration curves for converting corrected neutron counts to soil moisture content for the Bishes and Bennetts cosmicray soil moisture sensors. The dry soil counting rate, $N_{0}$, is 1583 counts per hour for Bishes and 1541 counts per hour for Bennetts.

pixels were grouped to produce a corresponding $5 \mathrm{~km}$ resolution product. AWRA-L soil moisture was reported in percentage capacity between 0 and $100 \%$ while the rover results were in volumetric units; no attempt was made to convert between units and the comparison focused on the strength of the fit between the datasets. 
Table 1. Side-by-side comparison of average neutron counts for the static CRNS's (Bishes and Bennetts) and the rover for four different $12 \mathrm{~h}$ periods. Also shown are the average soil moisture values for each date, static CRP to rover scaling factors and derived dry soil counting rate, $N_{0}$, for the rover. All counts are in counts per minute for application to rover data.

\begin{tabular}{llrrrrrr}
\hline Date & Site & $\begin{array}{r}\text { Static CRNS } \\
\text { average counts } \\
\text { (counts per minute) }\end{array}$ & $\begin{array}{r}\text { Static CRNS } \\
\text { average soil moisture } \\
\left(\mathrm{m}^{3} \mathrm{~m}^{-3}\right)\end{array}$ & $\begin{array}{r}\text { Rover average } \\
\text { counts } \\
\text { (counts per minute) }\end{array}$ & $\begin{array}{r}\text { Static to } \\
\text { rover scaling } \\
\text { factor }\end{array}$ & $\begin{array}{r}\text { Static CRNS } \\
N_{0}\end{array}$ \\
(counts per minute) & $\begin{array}{r}\text { Derived } \\
\text { rover } N_{0} \\
\text { (counts per minute) }\end{array}$ \\
\hline 10 Apr 2016 & Bishes & 21.74 & 0.08 & 370.0 & 17.0 & 26.4 \\
1 Mar 2017 & Bishes & 20.4 & 0.10 & 364.8 & 17.9 & 449 \\
9 Jun 2016 & Bennetts & 15.23 & 0.28 & 268.1 & 17.6 & 26.4 \\
2 Mar 2017 & Bennetts & 16.8 & 0.16 & 307.6 & 16.8 & 25.7 \\
\hline
\end{tabular}

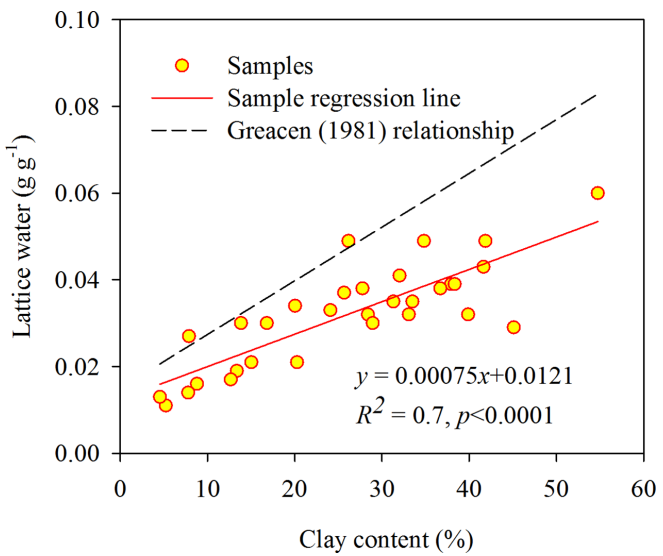

Figure 5. Clay content versus lattice water showing sample points from the study area and fitted relationship. Also shown for reference is the relationship proposed by Greacen (1981).

\section{Results}

\subsection{Static CRNS calibration}

Calibration of the two CRNS occurred under different soil moisture conditions; at Bennetts the depth-weighted soil moisture content was $0.13 \mathrm{~m}^{3} \mathrm{~m}^{-3}$, while at Bishes it was $0.08 \mathrm{~m}^{3} \mathrm{~m}^{-3}$. Fitting of the calibration curve to these two sites (Fig. 4) resulted in very similar dry soil $\left(N_{0}\right)$ counting rates, with analysis of the data collected at Bennetts producing an $N_{0}$ of 1541 counts per hour and that from Bishes producing an $N_{0}$ of 1583 counts per hour. Across the soil moisture range of 0 to $0.5 \mathrm{~m}^{3} \mathrm{~m}^{-3}$ the average soil moisture difference between the two curves in Fig. 4 was $0.019 \mathrm{~m}^{3} \mathrm{~m}^{-3}$. These differences are very small and reflect the fact that hydrogen represented by the biomass pool is basically nonexistent at these sites.

\subsection{Rover calibration}

Calibration of the rover was undertaken through side-by-side comparison with the Bennetts CRNS and the Bishes CRNS on two separate occasions each. These comparisons covered
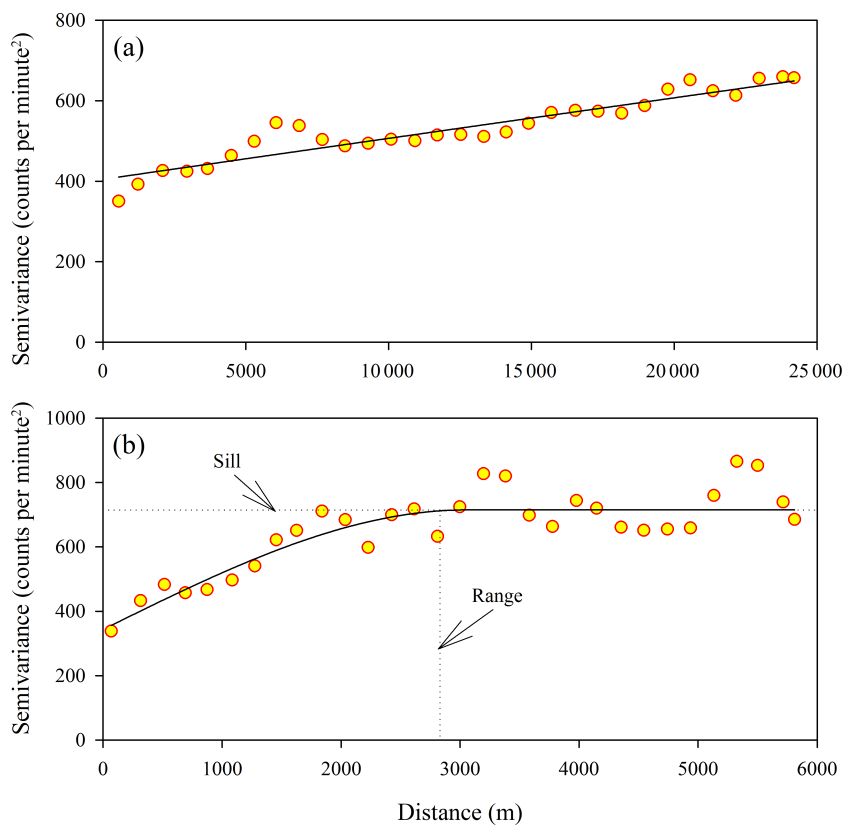

Figure 6. Example variograms used for block kriging for broad-scale and intensive surveys. The broad-scale variogram is from April 2016 (a) and the intensive-scale variogram is from June 2016 (b). The sill and the range are shown in (b).

a range of soil moisture conditions over four separate $12 \mathrm{~h}$ periods. Table 1 shows the corresponding neutron count rate for the rover and each CRNS and the scaling factor that converts static CRNS counting rate to a rover equivalent; this scaling factor is used to scale the $N_{0}$ values derived for each static sensor to an equivalent $N_{0}$ for the rover. Despite the differences in conditions and site characteristics, the scaling factor remained relatively constant, as did the derived $N_{0}$ for each comparison period. Given the relatively constant relationship between the rover and static sensors an average $N_{0}$ of 460 counts per minute was derived and this value was applied across all surveys. 

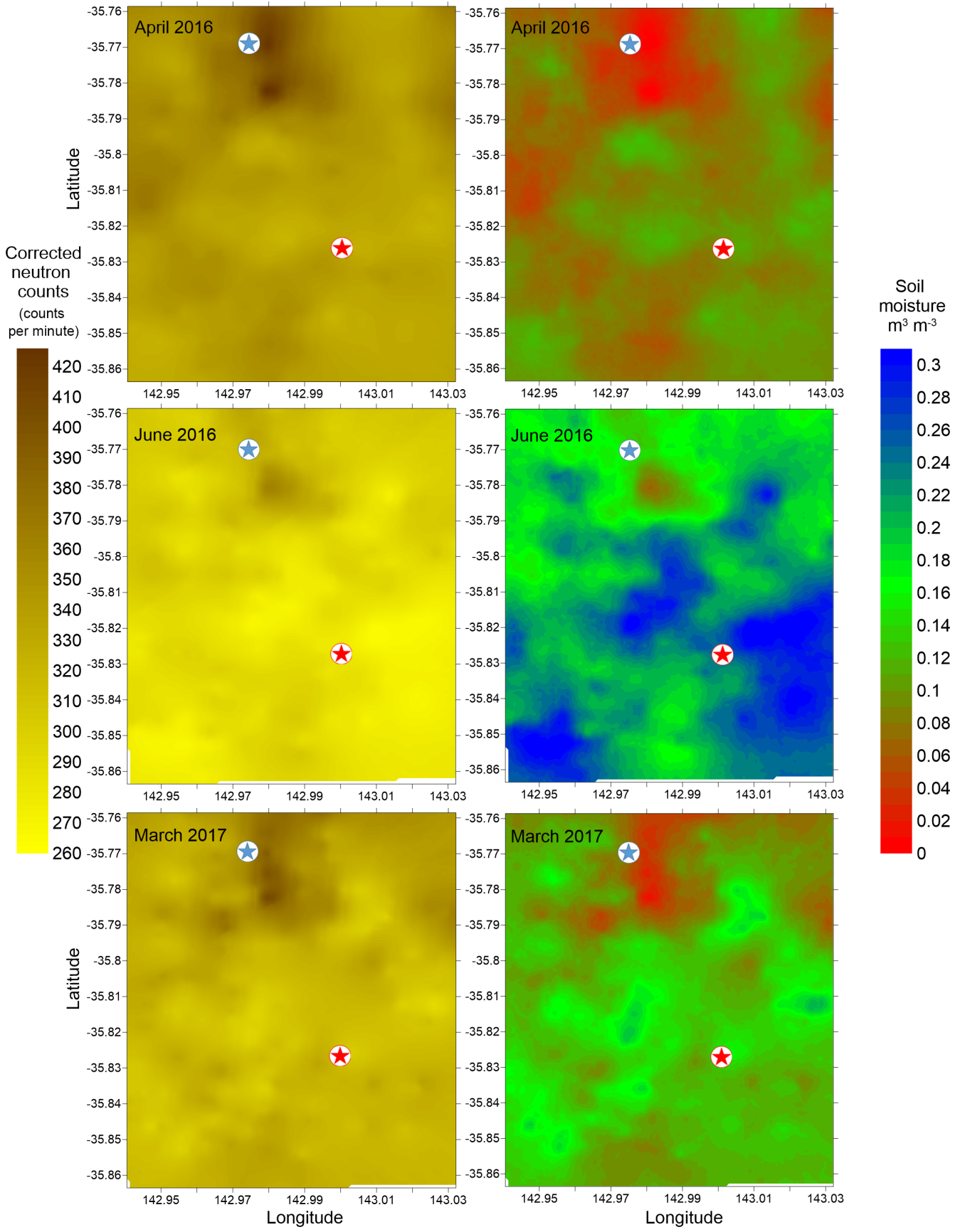

Figure 7. Interpolated corrected neutron counts (left column) and derived soil moisture (right column) for the three intensive-scale surveys during April 2016, June 2016 and March 2017. Blue and red stars indicate the location of the Bishes and Bennetts cosmic-ray neutron sensors.

\subsection{Spatial lattice water information}

A comparison of clay content and lattice water content for 36 spatially distributed samples shows a strong linear relationship $\left(R^{2}=0.7\right)$ across a broad range of clay content (4-56\%) (Fig. 5). This relationship was applied to the spatial clay content dataset from the Soil and Landscape Grid of Australia (Viscarra Rossel et al., 2014c) to produce an equivalent lattice water dataset at $90 \mathrm{~m}$ resolution which was utilised in rover surveys.

\subsection{Spatial estimation}

Example variograms from the kriging procedures used for broad-scale and intensive surveys are shown in Fig. 6. Both surveys utilise exponential variogram models; however, the 


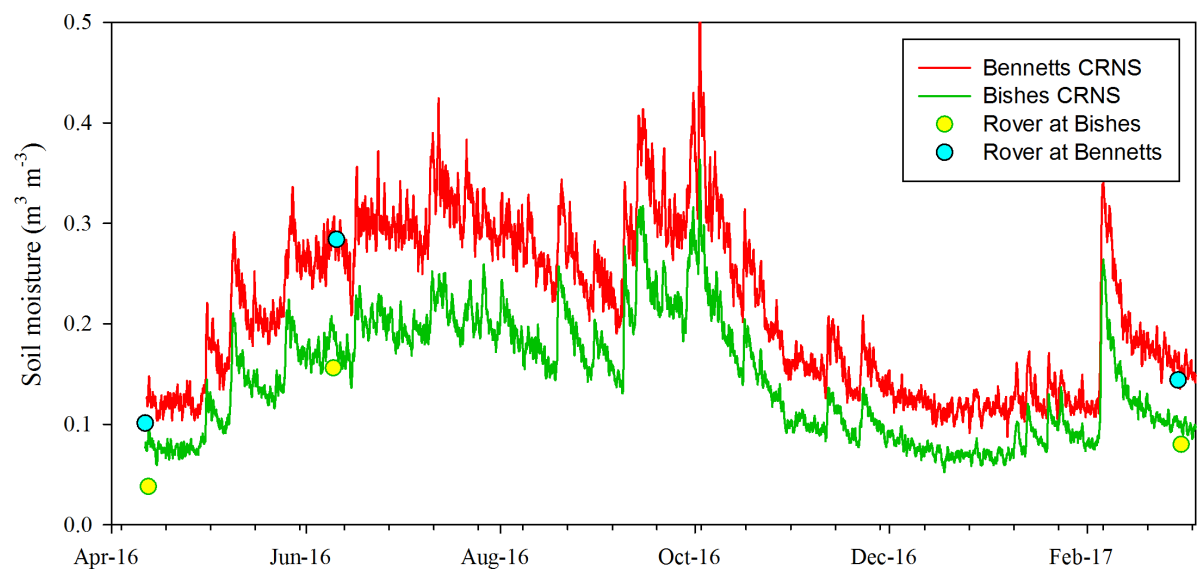

Figure 8. Comparison of Bennetts and Bishes CRNS soil moisture estimates and corresponding intensive rover survey estimates for the CRNS locations for the three survey dates. Rover survey estimate is from $1 \mathrm{~km}$ resolution pixel corresponding to each CRNS location.
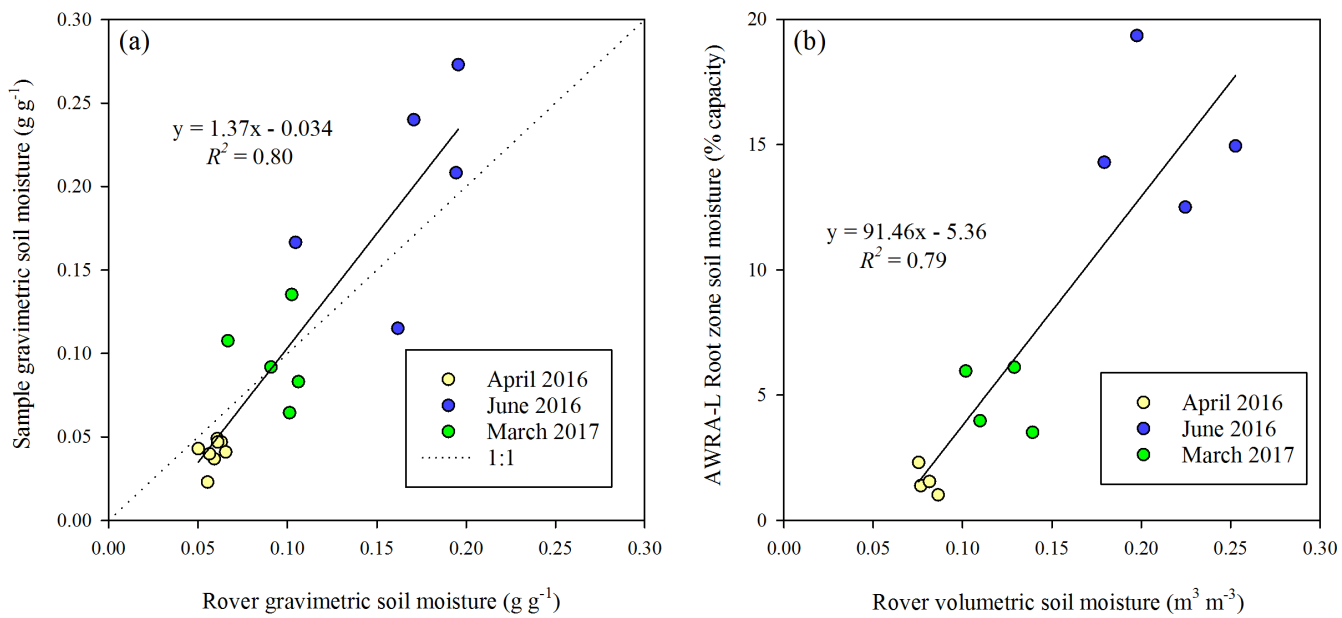

Figure 9. Intensive rover survey gravimetric soil moisture (1 km resolution) versus point sample gravimetric soil moisture (a) and intensive rover survey soil moisture (up-scaled to $5 \mathrm{~km}$ resolution) versus AWRA-L root zone soil moisture (5 $\mathrm{km}$ resolution).

fit is different, with the intensive-scale surveys having a distinct "sill" and broad-scale variograms showing no "sill" at all. The "sill" in a variogram represents the value at which the fitted model levels out (see Fig. 6). The presence of a sill indicates that there is a distance (known as the "range") between pairs of points beyond which there is no spatial correlation. The range is important as it is related to the spatial scale of the variability in neutron intensity. The lack of a sill for the broad-scale survey reflects differences in variability in neutron observations on this larger scale. The variogram model for the intensive surveys showed more cyclicity (or the "hole effect") which could be related to underlying geological periodicity (Yang and Kaleita, 2007). The empirical variograms were well described by the exponential models, giving confidence in interpolated rover counts across the respective survey areas.

\subsection{Intensive-scale rover surveys}

Interpolated counts and derived volumetric soil moisture content for each of the three intensive-scale surveys are shown in Fig. 7. A large range in soil moisture content was observed over the three surveys, with values ranging between $0.01 \mathrm{~m}^{3} \mathrm{~m}^{-3}$ in April 2016 through to $0.30 \mathrm{~m}^{3} \mathrm{~m}^{-3}$ in June 2016. Higher than average counting rates and, hence, lower soil moisture were consistently observed in the central northern region of the survey area. This area is characterised by a ridge of sandy soil with rock fragments and is known locally as "Sandhill". Wetter soil moisture conditions were observed through the central and southern parts of the survey area.

Comparison of intensive rover survey soil moisture estimates for the CRNS locations at the three different survey dates shows excellent agreement between the two measurement methods (Fig. 8). The rover survey estimate is taken 


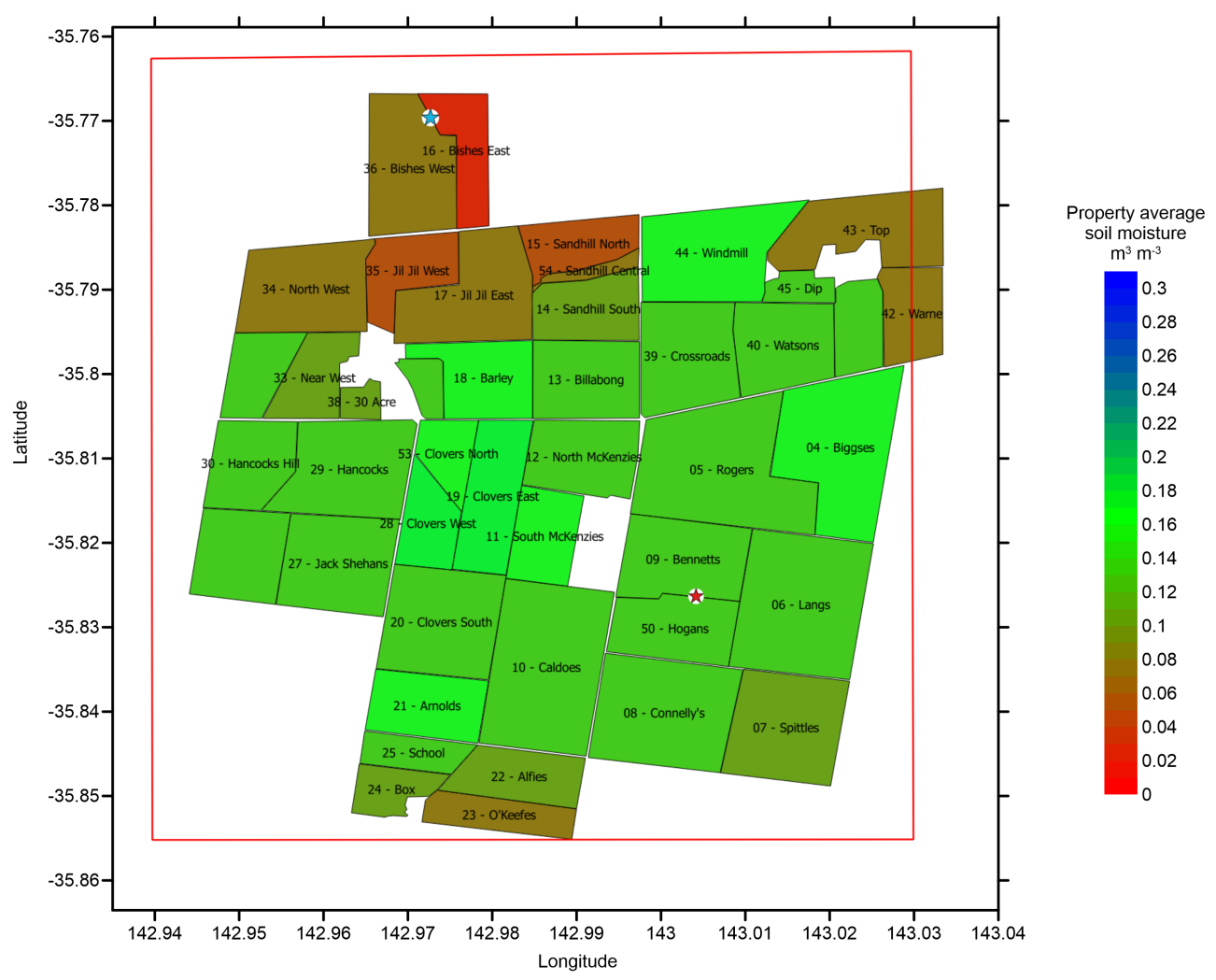

Figure 10. Location of target properties within the intensive-scale survey area (red box) and property-average soil moisture content for March 2017. Blue and red stars indicate the location of the Bishes and Bennetts cosmic-ray neutron sensors.

from the $1 \mathrm{~km}$ resolution soil moisture estimate for the corresponding CRNS pixel. Comparisons of estimates for the Bennetts CRNS shows differences of less than $0.025 \mathrm{~m}^{3} \mathrm{~m}^{-3}$ for all three occasions. The rover survey estimates tended to underestimate the soil moisture measured at the Bishes CRNS. The largest difference was during the April 2016 survey where soil moisture was underestimated by $0.04 \mathrm{~m}^{3} \mathrm{~m}^{-3}$. It is possible that this underestimation is a result of local interpolation issues. The Bishes CRNS is in close proximity to the sandy ridge known as Sandhill which represents a distinct zone of low soil moisture (Fig. 7). The effect of this abrupt change is likely to be "smoothed" within the area that also encompasses the Bishes CRNS.

Figure 9a shows a comparison of rover gravimetric soil moisture against corresponding soil moisture from the grab samples collected during each survey. The comparison shows strong correlation $\left(R^{2}=0.80\right)$ and data points are scattered around the $1: 1$ line. There is more scatter observed in the data under wetter conditions but this is likely to be related to a greater relative difference in spatial soil moisture following rainfall events. Similarly, the comparison of rover volumetric soil moisture against modelled root zone soil moisture from the AWRA-L model (Fig. 9b) also shows good correlation $\left(R^{2}=0.79\right)$. This comparison is complicated by the fact that the rover estimate represents an effective measurement depth of between 10 and $25 \mathrm{~cm}$ while the root zone soil moisture is an estimate between 0 and $100 \mathrm{~cm}$; despite this the agreement is still good. Comparison of these two independent soil moisture products with the rover surveys increases confidence in rover survey results on the intensive scale.

The rover surveys on the intensive scale also offer the opportunity to estimate soil moisture on the farm property scale. A number of properties in the intensive-scale zone are identified in Fig. 10 and the intensive-scale rover survey from March 2017 has been used to derive property-average soil moisture conditions in this figure. The average size of the identified properties is approximately $1 \mathrm{~km}^{2}$.

Point-to-area linear regression modelling based on continuous CRNS measurements from the Bennetts sensor and three intensive rover surveys was applied to 50 properties identified in the intensive survey area and very strong linear relationships were derived with an average $R^{2}$ value of 0.97 (range $=0.87-1.00$, see Table A1 in Appendix A for full results). We note here that only three surveys were available for developing these relationship, and further surveys and cross-validation are recommended for future work. Application of these regression models to derive time series of property-scale soil moisture for three example properties is given in Fig. 11. 


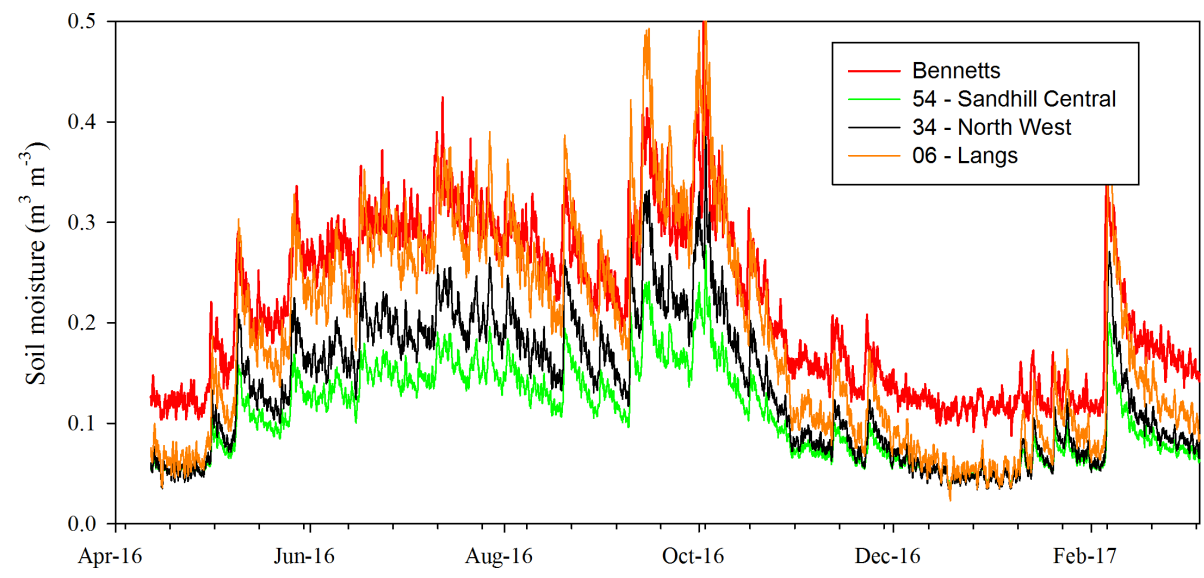

Figure 11. Time series of average soil moisture for selected properties in the intensive-scale survey area and corresponding soil moisture time series from the Bennetts cosmic-ray neutron sensor. Scaling relations ships are provided in Table A1.

\subsection{Broad-scale rover surveys}

Interpolated counts and derived volumetric soil moisture content for each of the three broad-scale surveys is shown in Fig. 12. The common feature of all of the survey dates is the tendency for higher counts and, hence, lower soil moisture to occur at the north-western region of the survey area and lower counts and, hence, higher soil moisture to occur in the south-eastern region. These patterns reflect soil textures in the region, with sandier soils and dunes with low clay content in the north-west and higher clay content soils in southeast. The driest soil moisture conditions were experienced during the April 2016 survey, with a mean soil moisture of $0.05 \mathrm{~m}^{3} \mathrm{~m}^{-3}$ (range $=0.01-0.10 \mathrm{~m}^{3} \mathrm{~m}^{-3}$ ), and the wettest were observed during the June 2016 survey, with a mean soil moisture of $0.17 \mathrm{~m}^{3} \mathrm{~m}^{-3}$ (range $=0.09-0.27 \mathrm{~m}^{3} \mathrm{~m}^{-3}$ ). The March 2017 survey provided intermediate soil moisture conditions with a mean for the region of $0.09 \mathrm{~m}^{3} \mathrm{~m}^{-3}$ (range $=0.04-0.15 \mathrm{~m}^{3} \mathrm{~m}^{-3}$ ).

Figure 13a shows a comparison of rover gravimetric soil moisture against corresponding soil moisture from the grab samples collected during each survey. The comparison shows reasonable correlation $\left(R^{2}=0.64\right)$ and data points tend to be scattered around the $1: 1$ line. Given the scale difference between these products ( $9 \mathrm{~km}$ versus point sample) the observed scatter is not surprising. Figure 13b shows a comparison of rover volumetric soil moisture against modelled root zone soil moisture from the AWRA-L model. The closer scale match between these two products $(9 \mathrm{~km}$ versus $5 \mathrm{~km})$, when compared to the point samples, results in a much higher correlation between the two datasets $\left(R^{2}=0.78\right)$. As with the intensive survey comparison, interpretation of the results is complicated because the measurement depth of the rover (10 to $25 \mathrm{~cm}$ ) is much less than the AWRA-L root zone soil moisture $(0$ to $100 \mathrm{~cm})$. Despite these differences the two products are still remarkably well correlated and the good agreement between the rover estimates and the AWRA-L es- timates, both spatially and across a range of soil moisture conditions, provides further evidence that the rover experimental design and data processing procedures are reliable.

Broad-scale survey soil moisture estimates were also tested by comparison with intensive survey results on scales of 1,3 and $9 \mathrm{~km}$ in an overlapping $9 \times 9 \mathrm{~km}$ region (Fig. 2). The difference in soil moisture estimates between the broadand intensive-scale surveys for different resolutions on each of the three survey dates is shown in Fig. 14. The broad-scale survey estimates are clearly not a good representation of $1 \times 1 \mathrm{~km}$ scale soil moisture as survey speeds and sampling points are not detailed enough to pick up local soil moisture variations at current counting rates. Differences of up to $\pm 0.10 \mathrm{~m}^{3} \mathrm{~m}^{-3}$ were observed. At $3 \times 3 \mathrm{~km}$ resolution the performance of the broad-scale survey estimates improves but there are still some distinct zones where soil moisture differed by as much as $\pm 0.06 \mathrm{~m}^{3} \mathrm{~m}^{-3}$. On the $9 \times 9 \mathrm{~km}$ scale, for which the broad-scale surveys were designed, differences in soil moisture between the intensive- and broad-scale surveys was minimal. On all three occasions the difference was less than $0.005 \mathrm{~m}^{3} \mathrm{~m}^{-3}$. These comparisons validate our broad-scale experimental design and give confidence in the $9 \times 9 \mathrm{~km}$ resolution soil moisture produced from our rover surveys.

\section{Discussion}

Static CRNS calibration at Bishes and Bennetts produced very similar dry soil counting rate $\left(N_{0}\right)$. This similarity has resulted because hydrogen in soil water, lattice water and organic matter is accounted for in the calibration process and because both sites are devoid of above-ground biomass. The effect of biomass on $N_{0}$ has been noted by Hawdon et al. (2014) who compared $N_{0}$ values from eight probes from across the Australian CRNS network with site biomass and also by Baatz et al. (2015) who proposed an empirical 


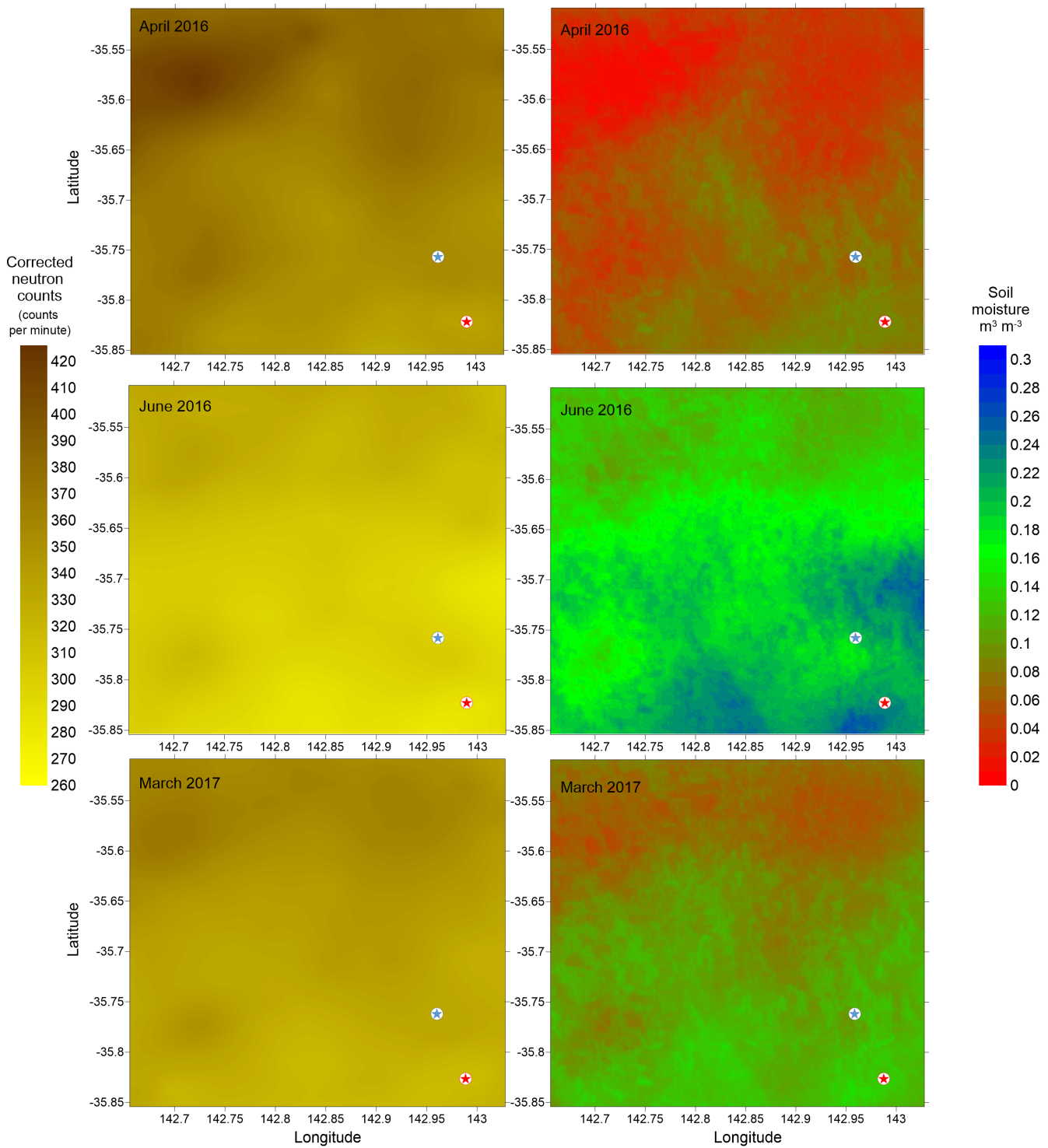

Figure 12. Interpolated corrected neutron counts (left column) and derived soil moisture (right column) for the three broad-scale surveys during April 2016, June 2016 and March 2017. Blue and red stars indicate the location of the Bishes and Bennetts cosmic-ray neutron sensors.

biomass correction for CRNS calibration. This finding has important implications for rover surveys in this region as the landscape in the Mallee region is almost entirely cleared of forest and above-ground biomass is represented by pasture and crop cover. McJannet et al. (2014) calculated that pasture represented a biomass water equivalent of just $0.6 \mathrm{~mm}$, a value similar to that derived by Baatz et al. (2015) for areas dominated by crops; these small values show that these small hydrogen pools will have little impact on neutron counts (McJannet et al., 2014).

In this present study the $N_{0}$ value for converting rover neutron counting rates to soil moisture content was derived through side by side comparison with the two CRNSs. A similar approach was employed by Chrisman and Zreda (2013) using a single CRNS as a reference point and by Dong et al. (2014) using a network of in situ measurements. Rover surveys undertaken by Franz et al. (2015) also used comparison with static CRNSs but in their investigations a further correction was introduced to account for variations in above-ground biomass. Locations with greater biomass should adopt calibration schemes that include this hydrogen pool (i.e. Baatz et al., 2015; Franz et al., 2013).

Rover surveys require information on the spatial variation in bulk density, soil organic matter and lattice water for calculation of soil moisture content using conventional approaches. While pre-existing bulk density and organic matter datasets exist for Australia we had to derive a lattice water dataset based on a strong region-wide relationship with clay 

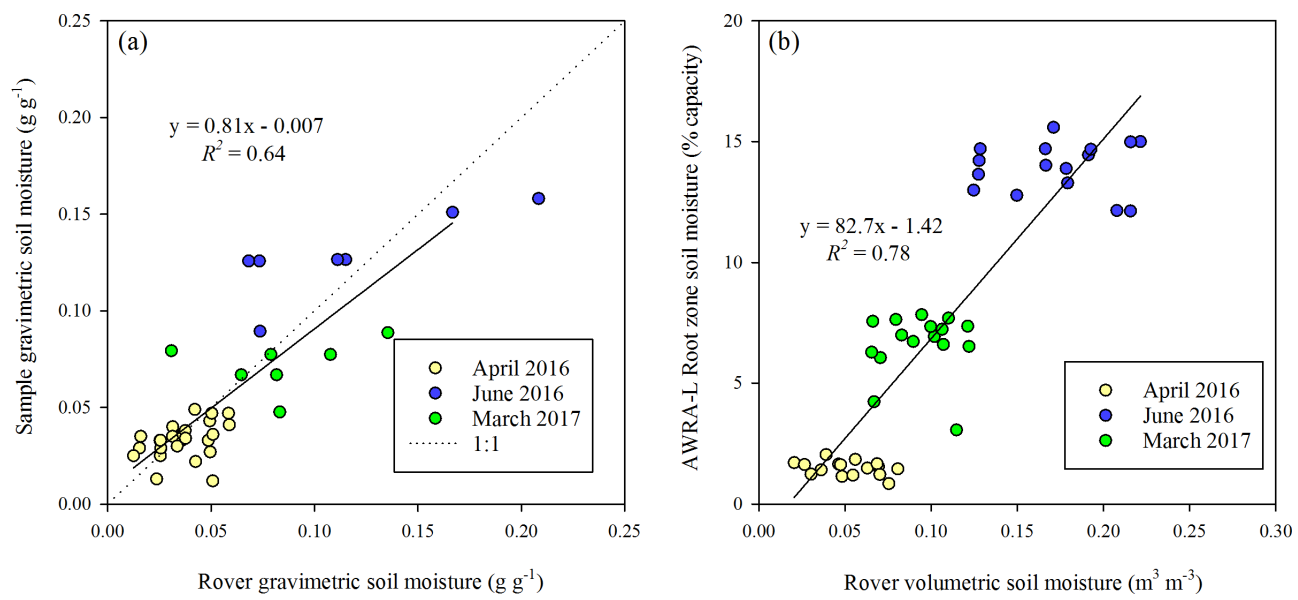

Figure 13. Broad-scale rover survey gravimetric soil moisture (9 $\mathrm{km}$ resolution) versus point sample gravimetric soil moisture (a) and broadscale rover survey soil moisture (9 km resolution) versus AWRA-L root zone soil moisture (5 km resolution).

content. The relationship we derived for the study area was different to that proposed by Greacen (1981) for Australian soils and may reflect differences in the soil types included in the analysis. With the intent of producing a similar spatial lattice water dataset for the continental United States, Avery et al. (2016) derived relationships with clay content but found that relationships were weak for many soil taxonomic groups. For best local results a spatial sampling such as that utilised in this present study is recommended.

A factor that has not been accounted for in our rover surveys is the potential impacts of roads on our survey results. By design roads will have a low moisture content and the impact of this narrow strip within the sensor footprint on survey results has not yet been accounted for in any operational rover studies reported in the literature. Using neutron modelling approaches, Köhli et al. (2015) demonstrated that a CRNS is most sensitive to soil moisture in the nearest tens of metres and showed that dry roads can contribute to an overestimate of neutron counts by a few percent. The dry roads will be over-represented in the measured neutron intensity as the sensitivity of neutron intensity to hydrogen is greater at the dry end of the scale (Andreasen et al., 2017a). A more recent study by Schrön et al. (2017) using neutron transport simulations and dedicated field experiments supports the findings of Köhli et al. (2015). Schrön et al. (2017) found that the effects of roads are greatest when surrounding soil moisture is much higher than road moisture content. In the survey areas in which our broad-scale rover surveys were undertaken, more than $70 \%$ of the roads were unsealed and many of the sealed roads were only one lane wide; while this does not remove the issue it does lessen the potential impact on reported results considerably. The impact of roads on our intensive-scale surveys is likely to be even less as $60 \%$ of the observations were made while driving around property boundaries (i.e. not properly formed roads) and a further $30 \%$ were on unsealed roads. While the impact of roads may not be a major issue for the present study it is an issue that warrants consideration in future surveys.

Intensive-scale surveys were designed to produce a $1 \times 1 \mathrm{~km}$ resolution soil moisture product, and comparison to static CRNS observations, spatially distributed point samples and AWRA-L model predictions support this. While the point samples and model estimates cannot be considered the "truth" they do provide a good guide as to rover performance and the agreement with these estimates provides confidence in intensive-scale rover results. Detailed soil moisture maps highlight the impact that soil properties have on observed soil moisture, with sandier locations being typically drier when compared to those with more clay. Property-scale soil moisture estimates led to the development of point-to-area style regression models which then enabled continuous estimates of soil moisture to be made on the property scale. Propertyscale regression models were strong but it is noted that these are based on data from three surveys. A more thorough investigation is recommended and this should include further surveys and cross-validation experiments. The opportunity also exists to use similar point-to-area scaling techniques to derive high temporal resolution soil moisture products at other set resolutions (e.g. $1 \mathrm{~km}$ ) which would make for ideal datasets for testing model and satellite soil moisture estimates. The regression modelling undertaken showed that temporal patterns in soil moisture were strong. Similar observations have been reported for other studies (Kachanoski and Jong, 1988; Grayson and Western, 1998; Vachaud et al., 1985). According to Yang and Kaleita (2007), spatial patterns of soil moisture exhibit some degree of temporal stability, which is related to time-invariant attributes such as topography and soil characteristics. With the relatively flat topography in Mallee study area and the assumption that rainfall inputs and crop growth are similar between properties, it is likely that differences in the slopes and intercepts of the relationship between CRNS observations and property-scale soil moisture 

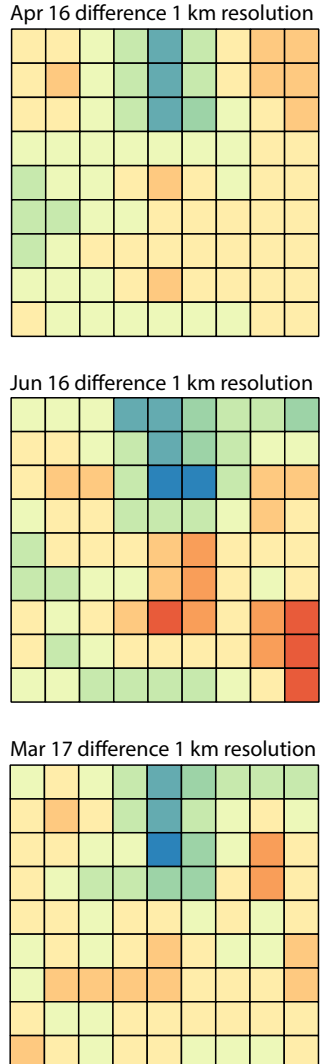

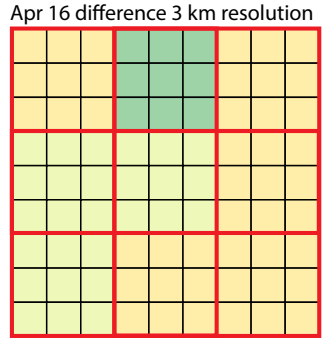

Jun 16 difference $3 \mathrm{~km}$ resolution
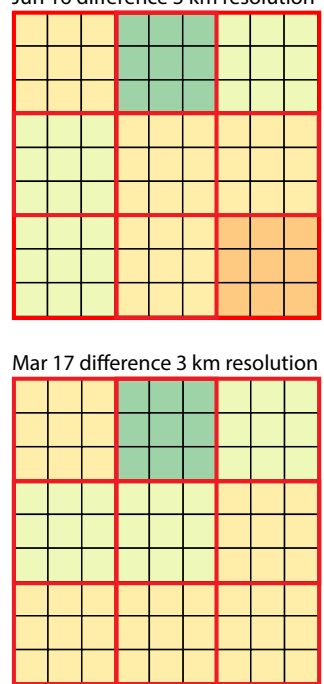

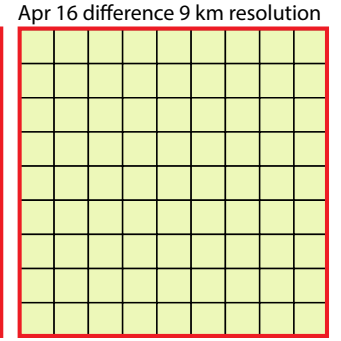

Soil moisture

difference

$\mathrm{m}^{3} \mathrm{~m}^{-3}$

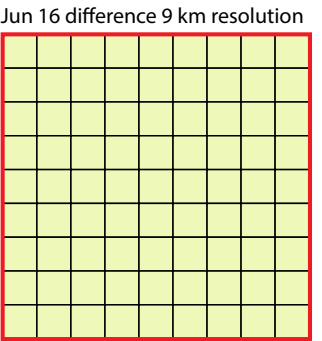

-0.10 to -0.08

-0.08 to -0.06

-0.06 to -0.04

-0.04 to -0.02

-0.02 to 0.00

0.00 to 0.02

0.02 to 0.04

0.04 to 0.06

0.06 to 0.08

0.08 to 0.10

Figure 14. Difference in soil moisture estimates between the broad- and intensive-scale surveys for different resolutions on each of the three survey dates. Each cell represents a $1 \mathrm{~km} \times 1 \mathrm{~km}$ region within the intensive survey zone.

(see Table A1) are being controlled by local soil characteristics. Changes in local crops and local-scale differences in rainfall inputs (i.e. small convective storms) do of course have the potential to change these point-to-area relationships but if these factors can be accounted for then useful spatial and temporal soil moisture datasets can be produced.

Comparison of broad-scale rover soil moisture estimates against those from point samples and the AWRA-L model showed good agreement across both space and time, thus providing further evidence that the rover experimental design and data processing procedures were reliable. Agreement between rover estimates and model estimates was particularly good and this reflects the closer match in scale of these two products. Comparison with emerging satellite, measurement and modelled soil moisture products will help to further assess rover approaches and results in the future. Broad-scale surveys produced reliable soil moisture estimates at $9 \times 9 \mathrm{~km}$ resolution, although the faster survey speeds and lower measurement density meant that this survey was unable to distinguish many of the smaller-scale soil moisture variations revealed at the finer resolution and slower survey speeds of the intensive-scale survey. This clearly supports the need to design rover surveys for the scale of analysis to be eventually undertaken.

\section{Conclusion}

In this study we presented an investigation designed to produce soil moisture estimates across a range of scales. Our investigation involved static CRNSs and rover surveys on both broad and intensive scales. We established techniques for converting neutron-counting rates from the rover to soil moisture using side-by-side comparisons with static CRNSs and spatial datasets of soil characteristics. In particular we found that lattice water was strongly related to clay content in the study area and used this relationship to derive a spatial representation of lattice water.

Rover surveys were undertaken across soils ranging in moisture content from 0.01 to $0.30 \mathrm{~m}^{3} \mathrm{~m}^{-3}$ and comparison with spatial distributed point samples and model estimates showed that reliable results were produced across all conditions. The slower driving speeds and denser sampling network of the intensive surveys provided representation of local soil moisture variations at resolutions down to $1 \times 1 \mathrm{~km}$. Stability in observed spatial patterns of soil moisture were used in a regression modelling approach to produce time series of property-scale soil moisture based on CRNS observations. Broad-scale surveys, which incorporated higher driving speeds and sparser sampling points, were shown to pro- 
duce excellent representations of soil moisture at $9 \times 9 \mathrm{~km}$ pixel resolution making them well suited for assessing variation in this parameter on a regional scale. The multiscale application of the rover makes it a unique tool for addressing soil moisture questions across scales previously not possible. The multiscale soil moisture products produced in this study are well suited to future analysis of both satellite soil moisture retrievals and finer-scale soil moisture models.
Data availability. Data used for this study are available from the lead author(david.mcjannet@csiro.au). 


\section{Appendix A}

Table A1. Supplementary information from regression analysis relating CRNS observations to property-average soil moisture content in the intensive-scale survey zone. The first line shown in italics is the static CRNS against which all properties are compared.

\begin{tabular}{|c|c|c|c|c|c|c|}
\hline \multirow[t]{2}{*}{ Property } & \multicolumn{3}{|c|}{ Soil moisture $\left(\mathrm{m}^{3} \mathrm{~m}^{-3}\right)$} & \multicolumn{3}{|c|}{ Regression modelling results } \\
\hline & April 2016 & June 2016 & Mar 2017 & Slope & Intercept & $R^{2}$ \\
\hline Bennetts CRNS & 0.124 & 0.277 & 0.157 & & & \\
\hline 54 - Sandhill Central & 0.065 & 0.152 & 0.080 & 0.575 & -0.008 & 0.999 \\
\hline 26 - Whirily & 0.103 & 0.294 & 0.140 & 1.257 & -0.055 & 1.000 \\
\hline 34 - North West & 0.070 & 0.199 & 0.095 & 0.848 & -0.036 & 0.999 \\
\hline 09 - Bennetts & 0.097 & 0.264 & 0.139 & 1.076 & -0.034 & 0.998 \\
\hline 21 - Arnolds & 0.079 & 0.216 & 0.147 & 0.809 & -0.003 & 0.905 \\
\hline $25-$ School & 0.082 & 0.222 & 0.136 & 0.858 & -0.013 & 0.968 \\
\hline 17 - Jil Jil East & 0.077 & 0.181 & 0.097 & 0.685 & -0.009 & 0.999 \\
\hline 14 - Sandhill South & 0.074 & 0.202 & 0.104 & 0.828 & -0.027 & 1.000 \\
\hline $24-$ Box & 0.079 & 0.223 & 0.118 & 0.922 & -0.032 & 0.997 \\
\hline 29 - Hancocks & 0.086 & 0.210 & 0.139 & 0.749 & 0.006 & 0.947 \\
\hline 13 - Billabong & 0.092 & 0.254 & 0.128 & 1.052 & -0.038 & 1.000 \\
\hline $38-30$ Acre & 0.081 & 0.187 & 0.106 & 0.688 & -0.003 & 1.000 \\
\hline 18 - Barley & 0.105 & 0.227 & 0.141 & 0.777 & 0.013 & 0.992 \\
\hline 16 - Bishes East & 0.027 & 0.132 & 0.057 & 0.674 & -0.053 & 0.995 \\
\hline 08 - Connelly’s & 0.093 & 0.223 & 0.123 & 0.845 & -0.011 & 1.000 \\
\hline 11 - South McKenzies & 0.106 & 0.261 & 0.144 & 1.003 & -0.016 & 0.999 \\
\hline $32-$ Far West & 0.063 & 0.192 & 0.124 & 0.765 & -0.016 & 0.919 \\
\hline 36 - Bishes West & 0.043 & 0.166 & 0.091 & 0.754 & -0.040 & 0.962 \\
\hline $40-$ Watsons & 0.092 & 0.222 & 0.125 & 0.839 & -0.009 & 0.998 \\
\hline $50-$ Hogans & 0.087 & 0.236 & 0.127 & 0.957 & -0.028 & 0.996 \\
\hline 51 - Hennessy’s & 0.089 & 0.254 & 0.159 & 1.000 & -0.019 & 0.947 \\
\hline $23-$ O'Keefes & 0.062 & 0.187 & 0.099 & 0.793 & -0.031 & 0.992 \\
\hline 22 - Alfies & 0.071 & 0.197 & 0.108 & 0.801 & -0.024 & 0.993 \\
\hline 15 - Sandhill North & 0.045 & 0.122 & 0.063 & 0.504 & -0.017 & 0.999 \\
\hline 35 - Jil Jil West & 0.057 & 0.164 & 0.072 & 0.721 & -0.036 & 0.995 \\
\hline 30 - Hancocks Hill & 0.054 & 0.188 & 0.128 & 0.770 & -0.020 & 0.865 \\
\hline 04 - Biggses & 0.097 & 0.242 & 0.153 & 0.891 & -0.002 & 0.964 \\
\hline 41 - Front & 0.095 & 0.193 & 0.127 & 0.620 & 0.023 & 0.985 \\
\hline 03 - Perns & 0.076 & 0.213 & 0.135 & 0.827 & -0.013 & 0.945 \\
\hline 45 - Dip & 0.095 & 0.213 & 0.135 & 0.734 & 0.011 & 0.982 \\
\hline 06 - Langs & 0.091 & 0.290 & 0.125 & 1.316 & -0.076 & 0.998 \\
\hline $07-$ Spittles & 0.094 & 0.275 & 0.119 & 1.216 & -0.063 & 0.993 \\
\hline 05 - Rogers & 0.084 & 0.224 & 0.121 & 0.896 & -0.024 & 0.997 \\
\hline 19 - Clovers East & 0.095 & 0.274 & 0.170 & 1.093 & -0.024 & 0.951 \\
\hline 10 - Caldoes & 0.081 & 0.205 & 0.129 & 0.758 & -0.003 & 0.965 \\
\hline 12 - North McKenzies & 0.089 & 0.269 & 0.140 & 1.149 & -0.048 & 0.995 \\
\hline 27 - Jack Shehans & 0.083 & 0.216 & 0.135 & 0.818 & -0.007 & 0.966 \\
\hline 42 - Warne & 0.066 & 0.189 & 0.089 & 0.807 & -0.035 & 0.999 \\
\hline 44 - Windmill & 0.077 & 0.220 & 0.147 & 0.848 & -0.010 & 0.911 \\
\hline 43 - Top & 0.074 & 0.206 & 0.093 & 0.883 & -0.040 & 0.995 \\
\hline 37 - Barrell & 0.095 & 0.206 & 0.129 & 0.701 & 0.013 & 0.991 \\
\hline 48 - Vernies & 0.082 & 0.200 & 0.103 & 0.781 & -0.017 & 0.999 \\
\hline 20 - Clovers South & 0.086 & 0.221 & 0.139 & 0.830 & -0.006 & 0.963 \\
\hline 33 - Near West & 0.067 & 0.206 & 0.106 & 0.889 & -0.039 & 0.995 \\
\hline 31 - Back Jack Shehans & 0.070 & 0.215 & 0.125 & 0.896 & -0.030 & 0.969 \\
\hline 28 - Clovers West & 0.093 & 0.260 & 0.166 & 1.004 & -0.014 & 0.940 \\
\hline 39 - Crossroads & 0.077 & 0.214 & 0.126 & 0.855 & -0.020 & 0.977 \\
\hline 53 - Clovers North & 0.079 & 0.229 & 0.151 & 0.893 & -0.013 & 0.917 \\
\hline
\end{tabular}


Competing interests. The authors declare that they have no conflict of interest.

Acknowledgements. The authors acknowledge the cooperation of Tim McClelland and family who allowed access to their properties for installations and surveys. We are grateful to staff from the Birchip Cropping Group who helped with surveys and sample analysis. Two anonymous reviewers, Christian Massari, Roland Baatz and Auro Almeida are thanked for their valuable review comments. Funding for this research was provided by the Department of Agriculture \& Water (grant agreement GMS-2582) and CSIRO. We acknowledge the NMDB database (http://www.nmdb.eu), founded under the European Union's FP7 programme (contract no. 213007) for providing neutron monitor data. Lomnický štít neutron monitor data (LMKS) were kindly provided by the Department of Space Physics, Institute of Experimental Physics, Košice, Slovakia. AWRA-L soil moisture estimates were provided by the Australian Bureau of Meteorology landscape water balance modelling program (http://www.bom.gov.au/water/landscape).

Edited by: Nunzio Romano

Reviewed by: Roland Baatz, Christian Massari, and two anonymous referees

\section{References}

Andreasen, M., Jensen, K. H., Desilets, D., Franz, T. E., Zreda, M., Bogena, H. R., and Looms, M. C.: Status and perspectives of the cosmic-ray neutron method for soil moisture estimation and other environmental science applications, Vadose Zone J., 16, https://doi.org/10.2136/vzj2017.04.0086, 2017a.

Andreasen, M., Jensen, K. H., Desilets, D., Zreda, M., Bogena, H. R., and Looms, M. C.: Cosmic-ray neutron transport at a forest field site: the sensitivity to various environmental conditions with focus on biomass and canopy interception, Hydrol. Earth Syst. Sci., 21, 1875-1894, https://doi.org/10.5194/hess-21-1875-2017, $2017 b$.

Anwar, M. R., O'Leary, G., McNeil, D., Hossain, H., and Nelson, R.: Climate change impact on rainfed wheat in south-eastern Australia, Field Crop. Res., 104, 139-147, https://doi.org/10.1016/j.fcr.2007.03.020, 2007.

Avery, W. A., Finkenbiner, C., Franz, T. E., Wang, T., NguyRobertson, A. L., Suyker, A., Arkebauer, T., and Muñoz-Arriola, F.: Incorporation of globally available datasets into the roving cosmic-ray neutron probe method for estimating field-scale soil water content, Hydrol. Earth Syst. Sci., 20, 3859-3872, https://doi.org/10.5194/hess-20-3859-2016, 2016.

Baatz, R., Bogena, H. R., Hendricks Franssen, H. J., Huisman, J. A., Qu, W., Montzka, C., and Vereecken, H.: Calibration of a catchment scale cosmic-ray probe network: A comparison of three parameterization methods, J. Hydrol., 516, 231-244, https://doi.org/10.1016/j.jhydrol.2014.02.026, 2014.

Baatz, R., Bogena, H. R., Hendricks Franssen, H. J., Huisman, J. A., Montzka, C., and Vereecken, H.: An empirical vegetation correction for soil water content quantification using cosmic ray probes, Water Resour. Res., 2030-2046, https://doi.org/10.1002/2014wr016443, 2015.
Baatz, R., Hendricks Franssen, H.-J., Han, X., Hoar, T., Bogena, H. R., and Vereecken, H.: Evaluation of a cosmic-ray neutron sensor network for improved land surface model prediction, Hydrol. Earth Syst. Sci., 21, 2509-2530, https://doi.org/10.5194/hess-212509-2017, 2017.

Bogena, H. R., Herbst, M., Huisman, J. A., Rosenbaum, U., Weuthen, A., and Vereecken, H.: Potential of Wireless Sensor Networks for Measuring Soil Water Content Variability All rights reserved. No part of this periodical may be reproduced or transmitted in any form or by any means, electronic or mechanical, including photocopying, recording, or any information storage and retrieval system, without permission in writing from the publisher, Vadose Zone J., 9, 1002-1013, https://doi.org/10.2136/vzj2009.0173, 2010.

Bogena, H. R., Huisman, J. A., Baatz, R., Hendricks Franssen, H. J., and Vereecken, H.: Accuracy of the cosmic-ray soil water content probe in humid forest ecosystems: The worst case scenario, Water Resour. Res., 49, 5778-5791, https://doi.org/10.1002/wrcr.20463, 2013.

Chrisman, B. and Zreda, M.: Quantifying mesoscale soil moisture with the cosmic-ray rover, Hydrol. Earth Syst. Sci., 17, 50975108, https://doi.org/10.5194/hess-17-5097-2013, 2013.

Desilets, D. and Zreda, M.: Spatial and temporal distribution of secondary cosmic-ray nucleon intensities and applications to in situ cosmogenic dating, Earth Planet. Sc. Lett., 206, 21-42, https://doi.org/10.1016/s0012-821x(02)01088-9, 2003.

Desilets, D. and Zreda, M.: Footprint diameter for a cosmic-ray soil moisture probe: Theory and Monte Carlo simulations, Water Resour. Res., 49, 3566-3575, https://doi.org/10.1002/wrcr.20187, 2013.

Desilets, D., Zreda, M., and Prabu, T.: Extended scaling factors for in situ cosmogenic nuclides: New measurements at low latitude, Earth Planet. Sc. Lett., 246, 265-276, https://doi.org/10.1016/j.epsl.2006.03.051, 2006.

Desilets, D., Zreda, M., and Ferre, T. P. A.: Nature's neutron probe: Land surface hydrology at an elusive scale with cosmic rays, Water Resour. Res., 46, W11505, https://doi.org/10.1029/2009wr008726, 2010.

Dong, J., Ochsner, T. E., Zreda, M., Cosh, M. H., and Zou, C. B.: Calibration and Validation of the COSMOS Rover for Surface Soil Moisture Measurement, Vadose Zone J., 13, https://doi.org/10.2136/vzj2013.08.0148, 2014.

Evans, J. G., Ward, H. C., Blake, J. R., Hewitt, E. J., Morrison, R., Fry, M., Ball, L. A., Doughty, L. C., Libre, J. W. Hitt, O. E., Rylett, D., Ellis, R. J., Warwick, A. C., Brooks, M., Parkes, M. A., Wright, G. M. H., Singer, A. C., Boorman, D. B., and Jenkins, A.: Soil water content in southern England derived from a cosmic-ray soil moisture observing system - COSMOS-UK, Hydrol. Process., 30, 4987-4999, https://doi.org/10.1002/hyp.10929, 2016.

Franz, T. E., Zreda, M., Ferre, T. P. A., Rosolem, R., Zweck, C., Stillman, S., Zeng, X., and Shuttleworth, W. J.: Measurement depth of the cosmic ray soil moisture probe affected by hydrogen from various sources, Water Resour. Res., 48, W08515, https://doi.org/10.1029/2012wr011871, 2012.

Franz, T. E., Zreda, M., Rosolem, R., and Ferre, T. P. A.: A universal calibration function for determination of soil moisture with cosmic-ray neutrons, Hydrol. Earth Syst. Sci., 17, 453-460, https://doi.org/10.5194/hess-17-453-2013, 2013. 
Franz, T. E., Wang, T., Avery, W., Finkenbiner, C., and Brocca, L.: Combined analysis of soil moisture measurements from roving and fixed cosmic ray neutron probes for multiscale real-time monitoring, Geophys. Res. Lett., 1-8, https://doi.org/10.1002/2015gl063963, 2015

Grayson, R. B. and Western, A. W.: Towards areal estimation of soil water content from point measurements: time and space stability of mean response, J. Hydrol., 207, 68-82, 1998.

Greacen, E. L. (Ed.): Soil water assessment by the neutron method, in: Soil water assessment by the neutron method, CSIRO Australia, Adelaide, 1981.

Hawdon, A., McJannet, D., and Wallace, J.: Calibration and correction procedures for cosmic-ray neutron soil moisture probes located across Australia, Water Resour. Res., 50, 5029-5043, https://doi.org/10.1002/2013wr015138, 2014.

Holgate, C. M., De Jeu, R. A. M., van Dijk, A. I. J. M., Liu, Y. Y., Renzullo, L. J., Vinodkumar, Dharssi, I., Parinussa, R. M., Van Der Schalie, R., Gevaert, A., Walker, J., McJannet, D., Cleverly, J., Haverd, V., Trudinger, C. M., and Briggs, P. R.: Comparison of remotely sensed and modelled soil moisture data sets across Australia, Remote Sens. Environ., 186, 479-500, https://doi.org/10.1016/j.rse.2016.09.015, 2016.

Kachanoski, R. and Jong, E.: Scale dependence and the temporal persistence of spatial patterns of soil water storage, Water Resour. Res., 24, 85-91, 1988.

Kędzior, M. and Zawadzki, J.: Comparative study of soil moisture estimations from SMOS satellite mission, GLDAS database, and cosmic-ray neutrons measurements at COSMOS station in Eastern Poland, Geoderma, 283, 21-31, https://doi.org/10.1016/j.geoderma.2016.07.023, 2016.

Klute, A.: Methods of soil analysis. Part 1. Physical and mineralogical methods, American Society of Agronomy, Inc., 1986.

Köhli, M., Schrön, M., Zreda, M., Schmidt, U., Dietrich, P., and Zacharias, S.: Footprint characteristics revised for field-scale soil moisture monitoring with cosmic-ray neutrons, Water Resour. Res., 51, 5772-5790, https://doi.org/10.1002/2015wr017169, 2015.

McJannet, D., Franz, T., Hawdon, A., Boadle, D., Baker, B., Almeida, A., Silberstein, R., Lambert, T., and Desilets, D.: Field testing of the universal calibration function for determination of soil moisture with cosmic-ray neutrons, Water Resour. Res., 50, 5235-5248, https://doi.org/10.1002/2014wr015513, 2014.

Minasny, B., McBratney, A. B., and Whelan, B. M.: VESPER version 1.62, The University of Sydney, NSW 2006, Australian Centre for Precision Agriculture, 2005.

Montzka, C., Bogena, H., Zreda, M., Monerris, A., Morrison, R., Muddu, S., and Vereecken, H.: Validation of Spaceborne and Modelled Surface Soil Moisture Products with Cosmic-Ray Neutron Probes, Remote Sens., 9, 103, https://doi.org/10.3390/rs9020103, 2017.

NASA: US standard atmosphere, 1976, NOAA-S/T, Washington D.C., 1976.

Ochsner, T. E., Cosh, M. H., Cuenca, R. H., Dorigo, W. A., Draper, C. S., Hagimoto, Y., Kerr, Y. H., Njoku, E. G., Small, E. E., and Zreda, M.: State of the Art in Large-Scale Soil Moisture Monitoring, Soil Sci. Soc. Am. J., 77, 1888-1919, https://doi.org/10.2136/sssaj2013.03.0093, 2013.
Rayment, G. E. and Higginson, F. R.: Australian laboratory handbook of soil and water chemical methods, Inkata Press Pty Ltd, 1992.

Renzullo, L. J., van Dijk, A. I. J. M., Perraud, J. M., Collins, D., Henderson, B., Jin, H., Smith, A. B., and McJannet, D. L.: Continental satellite soil moisture data assimilation improves rootzone moisture analysis for water resources assessment, J. Hydrol., 519, 3338-3352,

doi10.1016/j.jhydrol.2014.08.008, 2014.

Rivera Villarreyes, C. A., Baroni, G., and Oswald, S. E.: Inverse modelling of cosmic-ray soil moisture for field-scale soil hydraulic parameters, Eur. J. Soil Sci., 65, 876-886, https://doi.org/10.1111/ejss.12162, 2014.

Rosolem, R., Shuttleworth, W. J., Zreda, M., Franz, T. E., Zeng, X., and Kurc, S. A.: The Effect of Atmospheric Water Vapor on Neutron Count in the Cosmic-Ray Soil Moisture Observing System, J. Hydrometeorol., 14, 1659-1671, https://doi.org/10.1175/jhmd-12-0120.1, 2013.

Schrön, M., Rosolem, R., Köhli, M., Piussi, L., Schröter, I., Iwema, J., Kögler, S., Oswald, S., Wollschläger, U., and Samaniego, L.: The Cosmic-Ray Neutron Rover-Mobile Surveys of Field Soil Moisture and the Influence of Roads, Water Resour. Res., in review, 2017.

Smith, A. B., Walker, J. P., Western, A. W., Young, R. I., Ellett, K. M., Pipunic, R. C., Grayson, R. B., Siriwardena, L., Chiew, F. H. S., and Richter, H.: The Murrumbidgee soil moisture monitoring network data set, Water Resour. Res., 48, W07701, https://doi.org/10.1029/2012WR011976, 2012.

Vachaud, G., Passerat de Silans, A., Balabanis, P., and Vauclin, M.: Temporal stability of spatially measured soil water probability density function, Soil Sci. Soc. Am. J., 49, 822-828, 1985.

Van Dijk, A.: The Australian water resources assessment system, Technical Report 4, CSIRO, Canberra, 108 pp., 2010.

Vereecken, H., Huisman, J. A., Pachepsky, Y., Montzka, C., van der Kruk, J., Bogena, H., Weihermüller, L., Herbst, M., Martinez, G., and Vanderborght, J.: On the spatio-temporal dynamics of soil moisture at the field scale, J. Hydrol., 516, 76-96, https://doi.org/10.1016/j.jhydrol.2013.11.061, 2014.

Viney, N., Vaze, J., Crosbie, R., Wang, B., Dawes, W., and Frost, A.: AWRA-L v4. 5: technical description of model algorithms and inputs, CSIRO, Australia, 2014.

Vinodkumar Dharssi, I., Bally, J., Steinle, P., McJannet, D., and Walker, J.: Comparison of soil wetness from multiple models over Australia with observations, Water Resour. Res., 53, 633646, https://doi.org/10.1002/2015wr017738, 2017.

Viscarra Rossel, R., Chen, C., Grundy, M., Searle, R., Clifford, D., Odgers, N., Holmes, K., Griffin, T., Liddicoat, C., and Kidd, D.: Soil and Landscape Grid National Soil Attribute Maps - Bulk Density - Whole Earth ( $3^{\prime \prime}$ resolution) - Release 1. v4, CSIRO Data Collection, https://doi.org/10.4225/08/546EE212B0048, 2014a.

Viscarra Rossel, R., Chen, C., Grundy, M., Searle, R., Clifford, D., Odgers, N., Holmes, K., Griffin, T., Liddicoat, C., and Kidd, D.: Soil and Landscape Grid National Soil Attribute Maps - Organic Carbon (3" resolution) - Release 1. v1., CSIRO Data Collection, https://doi.org/10.4225/08/547523BB0801A, 2014b.

Viscarra Rossel, R., Chen, C., Grundy, M., Searle, R., Clifford, D., Odgers, N., Holmes, K., Griffin, T., Liddicoat, C., and Kidd, D.: Soil and Landscape Grid National Soil Attribute Maps - 
Clay ( 3 " resolution) - Release $1 . \mathrm{v} 4$, CSIRO Data Collection, https://doi.org/10.4225/08/546EEE35164BF, 2014c.

Wallace, J., Macfarlane, C., McJannet, D., Ellis, T., Grigg, A., and Dijk, A. v.: Evaluation of forest interception estimation in the continental scale Australian Water Resources Assessment - Landscape (AWRA-L) model, J. Hydrol., 499, 210-223, https://doi.org/10.1016/j.jhydrol.2013.06.036, 2013.

Western, A. W. and Blöschl, G.: On the spatial scaling of soil moisture, J. Hydrol., 217, 203-224, https://doi.org/10.1016/S00221694(98)00232-7, 1999.

Yang, L. and Kaleita, A. L.: Understanding Spatio-temporal Patterns of Soil Moisture at the Field Scale, American Society of Agricultural and Biological Engineers Annual International Meeting, Minneapolis, USA, 17-20 June 2007, ASABE Paper No. 072108, 2007.
Zreda, M., Desilets, D., Ferre, T. P. A., and Scott, R. L.: Measuring soil moisture content non-invasively at intermediate spatial scale using cosmic-ray neutrons, Geophys. Res. Lett., 35, L21402, https://doi.org/10.1029/2008g1035655, 2008.

Zreda, M., Shuttleworth, W. J., Zeng, X., Zweck, C., Desilets, D., Franz, T., and Rosolem, R.: COSMOS: the COsmic-ray Soil Moisture Observing System, Hydrol. Earth Syst. Sci., 16, 40794099, https://doi.org/10.5194/hess-16-4079-2012, 2012. 